\title{
Geostationary Communication Satellite Solar Array Optimization Using Gravitation Search Algorithm
}

Souad Oukil1 ${ }^{1, *}$, Abdelmadjid Boudjemai²

Oukil S (iD https://orcid.org/0000-0002-4677-0890

Boudjemai A (iD https://orcid.org/0000-0001-8916-0040

\section{How to cite}

Oukil S; Boudjemai A (2020) Geostationary Communication Satellite Solar Array Optimization Using Gravitation Search Algorithm. J Aerosp Technol Manag, 12: e4420. https://doi. org/10.5028/jatm.v12.1165

ABSTRACT: The preliminary design of geostationary communication satellite solar array is presented in this work. Based on the power requirements, power margin requirements and performance requirements, the number of panels, strings and cells to be used on the solar array were defined. The main objective of this study was to optimize the power generated from the satellite solar array and the extraction of the parameters of a photovoltaic module, which is subject to the space environment and under a series of practical constraints, in order to extract the desired performance parameters for multiobjective functions, taking into account the solstice and equinox periods during temperature operation. A gravitational search algorithm based on the law of gravity and mass interactions was introduced. This algorithm has proved its effectiveness in optimizing system parameters in the literature. From the results obtained in this work, the total power of the optimized system was reduced by $181 \mathrm{~W}$. The degradation and output power characteristics of the solar panels were calculated for different temperature values.

KEYWORDS: Solar arrays; Satellite; Power; Temperature; Degradation.

\section{INTRODUCTION}

The growing demand for satellite communications with high subsystems reliability and the increasing complexity of satellite power subsystems that use large deployable solar panels and appropriate electronics modules, with increasing embedded satellite payloads, are needs that make a difficult task even more difficult. Therefore, effective optimization techniques are required to help engineers and decision makers configure satellite power subsystems well in terms of performance and reliability.

One of the important requirements in each space mission is the design of a system to provide uninterruptible energy with desired quality and quantity. The satellite power subsystem project must satisfy its demand for electricity during the mission.

To obtain this electrical energy, it is necessary to calculate the required area of the satellite structure for the installation of solar panels. Also, the number of strings, serial cells in each string and the size of the cells (Kimber and Gleeson 1988; Kimber and Goodbody 1994) must be defined in the design of each solar panel. As mentioned, the design of a solar array on a specific space mission is based on the mission requirements. Solar cells are still the most suitable energy source in space missions. The behavior of solar cells is strongly related to environmental conditions (Castañer and Silvestre 2002; Luque and Hegedus 2003). 
Degradation is an important factor in space missions, which, compared to terrestrial applications, has direct effects on the performance of solar cells. Taking into account the mentioned factor, the generated power of a solar array can be estimated more accurately in space missions before launch or during the mission (Taherbaneh et al. 2011).

The production of solar energy necessary to supply large satellites with high power demand is ensured by the deployment of large solar panels with highly reliable mechanisms, also robust distribution and conditioning electronics, and finally a powerful energy storage system. To meet these requirements, the use of optimization tools has become an essential area to solve many problems encountered in the space industry. In fact, during the last few years, a very rapid growth of works using optimization methods has been observed.

Multiobjective optimization is a very active field of research because the economic and industrial risks are enormous. Multiobjective optimization methods provide the designer with a set of solutions corresponding to as many compromises between the different antagonistic objectives of the problem.

In this work, a gravitational search algorithm (GSA) was introduced in order to estimate the solar panel parameters of the single diode model for several cases, based on the experience gained from first Algerian geostationary communication satellite Alcomsat-1 project.

The paper deals with the extraction of the parameters of a photovoltaic (PV) module of geostationary satellite, using multiobjective functions taking into account the solstice (SS) and equinox (EQX) periods during temperature operation, as well as in the case of the degradation effect in order to achieve the overall minimum solution in a very short time with very good accuracy. The results of the simulation show that the GSA algorithm has achieved the best efficiency for modeling the photovoltaic cell as well as the PV module of a geostationary satellite.

\section{RELATED WORK}

Several researchers have proposed to identify the different parameters affecting the characteristics of the power system by applying several optimization methods, namely deterministic and heuristic methods (Wei et al. 2011; El-Naggar et al. 2012; Harrag and Messalti 2017). A comparative study of four methods to extract solar cell parameters from the single diode lumped circuit model was carried out by Chegaar et al. (2003). Other study has been developed by Xiao et al. (2006) based on the application of the real-time estimation method that uses polynomials to demonstrate the power-voltage relationship of photovoltaic panels and by the implementation of the recursive least squares method and the Newton-Raphson method, in order to identify the optimal operating point voltage. A mathematical model has been developed for the energy performance of PV modules, which depends on the irradiance in the plane and the temperature of the module (Huld et al. 2010).

Other studies have been based on the use of different methods and techniques. A particular study was carried out by researchers applying the nonlinear least squares optimization algorithm and which established the modified Newton model with the Levenberg parameter was applied for the extraction of the five parameters of solar cell illuminated from experimental data (Easwarakhanthan et al. 1986). Ortiz-Conde et al. (2006) have used a new method based on the computation of the cocontent function from the exact and explicit analytical solutions of the characteristics of the illuminated current voltage (I-V). As for the research conducted for AlRashidi et al. (2011), an application of a new model search optimization technique has been employed to estimate parameters of a solar cell and a PV module. Ishaque and Salam (2011) used a method based on differential evolution, which consists of simultaneously calculating all the parameters of a photovoltaic module at different levels of irradiance and temperature with an experiment of three PV modules of different types (multicrystalline, monocrystalline and thin film). In photovoltaic (PV) generation system, to obtain the maximum available energy from PV source using highly efficient power conditioning system is an important issue because the characteristic of real PV panel is always changing with dynamic irradiance and temperature conditions (Cubas et al. 2014; Park and Choi 2017). Derick et al. (2017) applied the wind driven optimization technique to identify solar PV parameters. The precision and convergence time of the proposed method are compared to several other algorithms.

Other researchers have proposed an extension of the gravitational research algorithm (GSA) to multiobjective optimization problems and its application in various fields, including the power system. Ghasemi et al. (2013) discuss the design of multimachine power system stabilizers using a fuzzy GSA. Mondal et al. (2013) solve the multiobjective economic emission load dispatch problem considering wind power penetration. Tian et al. (2014) discuss the multiobjective optimization of short-term hydrothermal scheduling using a nondominated sorting GSA with chaotic mutation. Bhattacharya and Roy (2012) have applied an efficient and reliable heuristic technique inspired by swarm behaviors and GSA algorithm for solution of multiobjective optimal power flow (OPF) problems.

The comparison of the related work references, are summarized in Table 1. 
Table 1. Comparison of the related work references.

\begin{tabular}{|c|c|c|c|c|}
\hline Reference & Author & Algorithm & Advantages & Disadvantages \\
\hline Wei et al. (2011) & H. Wei & $\begin{array}{l}\text { Proposed a chaotic particle } \\
\text { swarm optimization } \\
\text { algorithm (CPSO) for } \\
\text { extracting solar cell model } \\
\text { parameters. }\end{array}$ & $\begin{array}{l}\text { It can reduce the influence } \\
\text { of experimental data } \\
\text { measurement accuracy. }\end{array}$ & $\begin{array}{l}\text { It sometimes easily gets } \\
\text { trapped in a local optimum } \\
\text { and the convergence rate } \\
\text { decreases considerably in } \\
\text { the later period of evolution. }\end{array}$ \\
\hline El-Naggar et al. (2012) & KM. El-Naggar & $\begin{array}{l}\text { Proposed a simulated } \\
\text { annealing (SA) based } \\
\text { approach for optimal } \\
\text { estimation of solar cell } \\
\text { model parameters. }\end{array}$ & $\begin{array}{l}\text { It was used to solve a } \\
\text { transcendental function that } \\
\text { governs the current-voltage } \\
\text { relationship of a solar cell, as } \\
\text { no direct general analytical } \\
\text { solution exists. }\end{array}$ & $\begin{array}{l}\text { Repeatedly annealing } \\
\text { with a schedule is very } \\
\text { slow, especially if the cost } \\
\text { function is expensive to } \\
\text { compute. }\end{array}$ \\
\hline $\begin{array}{l}\text { Harrag and Messalti } \\
\qquad(2017)\end{array}$ & A. Harrag & $\begin{array}{l}\text { Proposed a particle swarm } \\
\text { optimization technique for } \\
\text { the characterization of the } \\
\text { equivalent electrical model } \\
\text { of photovoltaic cell. }\end{array}$ & $\begin{array}{l}\text { It has fast convergence } \\
\text { towards an optimum, is } \\
\text { simple to compute, easy to } \\
\text { implement. }\end{array}$ & $\begin{array}{l}\text { When reaching a near } \\
\text { optimal solution, the } \\
\text { algorithm stops optimizing } \\
\text { and the accuracy that the } \\
\text { algorithm can achieve is } \\
\text { limited. }\end{array}$ \\
\hline Chegaar et al. (2003) & M. Chegaar & $\begin{array}{l}\text { Proposed the vertical } \\
\text { optimization method, } \\
\text { the analytical five-point } \\
\text { method, and their methods } \\
\text { for extracting solar cell } \\
\text { parameters of the single } \\
\text { diode lumped circuit model. }\end{array}$ & $\begin{array}{c}\text { It does not require a } \\
\text { priori knowledge of the } \\
\text { parameters. }\end{array}$ & $\begin{array}{l}\text { In the case of the module, } \\
\text { the calculated saturation } \\
\text { current is far higher than } \\
\text { that obtained numerically } \\
\text { and it does not give all the } \\
\text { parameters simultaneously. }\end{array}$ \\
\hline Xiao et al. (2006) & W. Xiao & $\begin{array}{l}\text { Proposed a method of } \\
\text { real-time estimation uses } \\
\text { polynomials to demonstrate } \\
\text { the power-voltage } \\
\text { relationship of PV panels. }\end{array}$ & $\begin{array}{l}\text { It implements the recursive } \\
\text { least-squares method and } \\
\text { Newton-Raphson method } \\
\text { to identify the voltage of the } \\
\text { optimal operating point. }\end{array}$ & $\begin{array}{c}\text { In several cases, this method } \\
\text { is found to be highly } \\
\text { unstable for poor initial } \\
\text { guess. }\end{array}$ \\
\hline Huld et al. (2010) & T. Huld & $\begin{array}{l}\text { Proposed to mapping } \\
\text { the performance of PV } \\
\text { modules, effects of module } \\
\text { type and data averaging to } \\
\text { estimate the energy yield of } \\
\text { photovoltaic modules. }\end{array}$ & $\begin{array}{l}\text { Data of arbitrary locations } \\
\text { in a large geographical area } \\
\text { was used. }\end{array}$ & $\begin{array}{l}\text { It takes more time to run } \\
\text { simulations compared to } \\
\text { other methods. }\end{array}$ \\
\hline $\begin{array}{l}\text { Easwarakhanthan et al. } \\
\text { (1986) }\end{array}$ & T. Easwarakhanthan & $\begin{array}{l}\text { Proposed a nonlinear } \\
\text { least-squares optimization } \\
\text { algorithm based on the } \\
\text { Newton model modified } \\
\text { with Levenberg parameter, } \\
\text { for the extraction of solar } \\
\text { cell parameters from the } \\
\text { experimental data. }\end{array}$ & $\begin{array}{l}\text { The program allows an in } \\
\text { situ theoretical modeling } \\
\text { of solar cells in laboratories } \\
\text { when incorporated into } \\
\text { microcomputer-based data } \\
\text { acquisition software. }\end{array}$ & $\begin{array}{l}\text { For flat functions (i.e. } \\
\text { smooth functions with } \\
\text { derivatives that vanish at a } \\
\text { certain point), the algorithm } \\
\text { can get lost in parameter } \\
\text { space. In some cases, the } \\
\text { algorithm can be very slow } \\
\text { to converge. }\end{array}$ \\
\hline $\begin{array}{l}\text { Ortiz-Conde et al. } \\
\text { (2006) }\end{array}$ & A. Ortiz-Conde & $\begin{array}{l}\text { Proposed a new method } \\
\text { to extract the intrinsic and } \\
\text { extrinsic model parameters } \\
\text { of illuminated solar cells. }\end{array}$ & $\begin{array}{l}\text { It was based on calculating } \\
\text { the cocontent function from } \\
\text { the exact explicit analytical } \\
\text { solutions of the illuminated } \\
\text { current-voltage (I-V) } \\
\text { characteristics. }\end{array}$ & $\begin{array}{l}\text { The mathematical } \\
\text { expressions of module } \\
\text { parameters are usually } \\
\text { nonlinear and require } \\
\text { iterative numerical } \\
\text { solutions. }\end{array}$ \\
\hline AlRashidi et al. (2011) & MR. AlRashidi & $\begin{array}{l}\text { Proposed a new technique } \\
\text { based on pattern search } \\
\text { optimization for estimating } \\
\text { different solar cell } \\
\text { parameters. }\end{array}$ & $\begin{array}{l}\text { It has fast convergence } \\
\text { towards an optimum, is } \\
\text { simple to compute and easy } \\
\text { to implement. }\end{array}$ & $\begin{array}{l}\text { Near optimal solution, the } \\
\text { algorithm stops optimizing } \\
\text { and the accuracy the } \\
\text { algorithm can achieve is } \\
\text { limited. }\end{array}$ \\
\hline
\end{tabular}


Table 1. Continuation.

\begin{tabular}{|c|c|c|c|c|}
\hline Reference & Author & Algorithm & Advantages & Disadvantages \\
\hline $\begin{array}{l}\text { Ishaque and Salam } \\
\qquad(2011)\end{array}$ & K. Ishaque & $\begin{array}{l}\text { Proposed an improved } \\
\text { modeling approach using } \\
\text { differential evolution } \\
\text { method to determine } \\
\text { the model parameters of } \\
\text { photovoltaic modules. }\end{array}$ & $\begin{array}{l}\text { It gives superior results } \\
\text { for any irradiance and } \\
\text { temperature variations } \\
\text { and can be useful for PV } \\
\text { simulator developers. }\end{array}$ & $\begin{array}{l}\text { It can create a problem of } \\
\text { a slow convergence and it } \\
\text { also easily falls into the local } \\
\text { optimum. }\end{array}$ \\
\hline Cubas et al. (2014) & J. Cubas & $\begin{array}{l}\text { Proposed a new analytical } \\
\text { method based on a reduced } \\
\text { amount of information, } \\
\text { consisting in the normal } \\
\text { manufacturer data. }\end{array}$ & $\begin{array}{l}\text { Analytical methods are } \\
\text { proposed to express } \\
\text { equivalent circuit } \\
\text { parameters in terms of } \\
\text { performance characteristics } \\
\text { of the PV module. }\end{array}$ & $\begin{array}{c}\text { Equivalent circuit } \\
\text { parameters are estimated } \\
\text { if module performance } \\
\text { is known under some } \\
\text { operating conditions } \\
\text { with some simplifying } \\
\text { assumptions. }\end{array}$ \\
\hline Park and Choi (2017) & J-Y. Park & $\begin{array}{c}\text { Proposed a new simulation } \\
\text { model for PV panels using } \\
\text { online datasheet parameter } \\
\text { tuning. }\end{array}$ & $\begin{array}{l}\text { Not only applied to the } \\
\text { other simulation programs } \\
\text { but also used as the PV } \\
\text { simulation engine in PV } \\
\text { hardware simulators. }\end{array}$ & $\begin{array}{l}\text { It needs much more } \\
\text { computational time. }\end{array}$ \\
\hline Derick et al. (2017) & M. Derick & $\begin{array}{l}\text { Proposed a wind driven } \\
\text { optimization (WDO) } \\
\text { technique to identify } \\
\text { the solar photovoltaic } \\
\text { parameters. }\end{array}$ & $\begin{array}{l}\text { Strong global search ability } \\
\text { and robustness, and high } \\
\text { calculation accuracy. }\end{array}$ & $\begin{array}{l}\text { Derivation equation are } \\
\text { more complicated and } \\
\text { difficult to understand. }\end{array}$ \\
\hline
\end{tabular}

\section{GEOSTATIONARY COMMUNICATION SATELLITE ELECTRICAL POWER SUBSYSTEM REQUIREMENTS}

The required concept for power distribution unit and management is essentially determined by the electrical power subsystem architecture. State-of-the-art power distribution unit and management concepts use either regulated or nonregulated primary power buses, or, in a combination of both methods, a semiregulated and hybrid power supply system.

The primary power of the spacecraft, in most cases generated by a solar array, will be fed into the main power bus of the electrical power subsystem by direct or indirect energy transfer, when necessary to cover the bus power demand. Power transfer from the solar array to the main bus by direct energy transfer corresponding to the amount of power necessary to satisfy the bus power demand will be achieved by regulation methods (Ley et al. 2009).

The solar array consists of two identical wings extending symmetrically from the north and south sidewalls of the satellite, for a better symmetrical momentum. The rigid solar array consists of numerous solar cells mounted on a base substrate made of aluminum honeycomb with face sheets made of fiber composite. The objective of this fiber sheets aims to reduce the weight.

As shown in Fig. 1, each wing is made of one yoke and two panels connected by hinges and close cable loops.

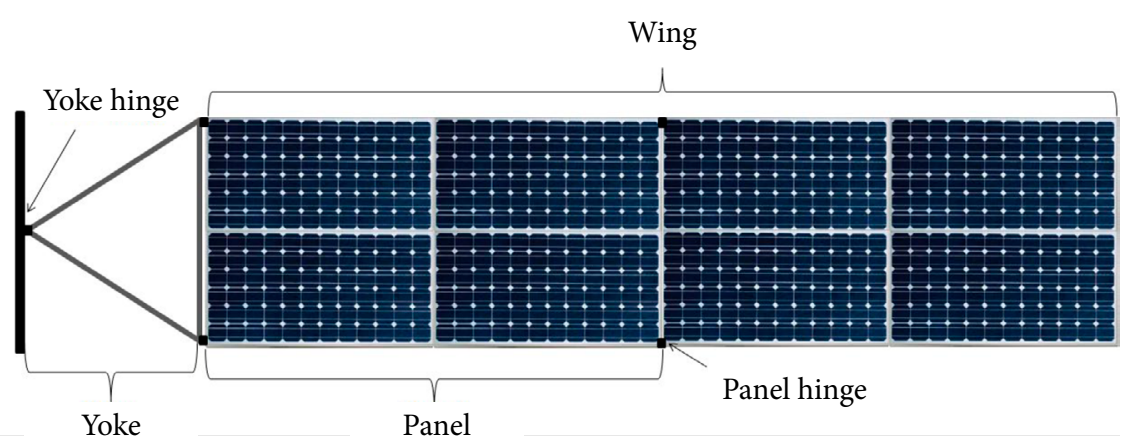

Figure 1. Deployed wing of the solar array. 
Figure 2 shows that the wings are stowed against the south and north side walls of the spacecraft by hold and release mechanism during launch. After the spacecraft separation from the launch vehicle, the hold-down pins are cut off and the solar array is deployed by the springs integrated in the hinges. The mechanical and electrical interfaces to the satellite are made at the solar array drive assembly (SADA) on the satellite sidewall. The SADA slowly rotates the wing to track the sun while the satellite maintains Earth pointing.

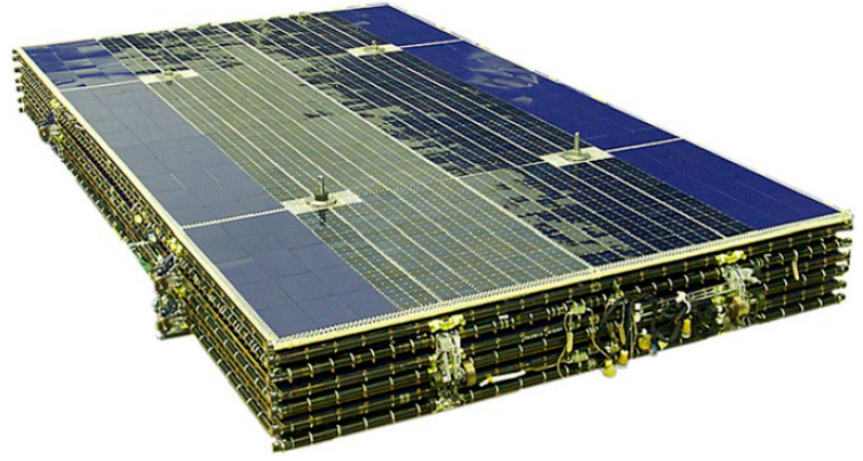

Figure 2. Morozov and Lopatin [2011) stowed wing of the solar array. Courtesy of ISS-Reshetnev Company.

The design of a solar array in a specific space mission is based on the mission requirements. Table 2 provides the required electrical specifications of the solar panel for the beginning of life (BOL) and the end of life (EOL) of the mission at solstice and equinox season. Note that the desired solar array power shall be higher than the values indicated in Table 2.

Table 2. Electrical power requirements of the solar panel.

\begin{tabular}{|c|l|c|c|}
\hline & & Solstice [SS] & Equinox [EQX) \\
\hline BOL & Requirements (W) & 2098 & 2369 \\
\hline EOL & Requirements (W) & 1913 & 2155 \\
\hline
\end{tabular}

To select the appropriate solar cells, the following parameters are very important: required electrical power, solar cell technology, resistance against orbital radiations and operating temperature range. Considering all the above parameters, the cells shall be of the triple junction gallium arsenide (TJ GaAs) manufacturing type with cell area of $26 \mathrm{~cm}^{2}$, measured at $28{ }^{\circ} \mathrm{C}$, as shown in Table 3 .

Table 3. Triple junction gallium arsenide (TJ GaAs) main characteristics at $\mathrm{BOL}$ at $28^{\circ} \mathrm{C}$.

\begin{tabular}{|c|c|c|c|c|c|c|c|c|}
\hline $\begin{array}{l}V_{m p} \\
(\mathbf{V})\end{array}$ & $\begin{array}{l}V_{o c} \\
{[\mathbf{V}]}\end{array}$ & $I_{\text {Imp }}$ & $\frac{I_{s c}}{\left[A / \mathrm{cm}^{2}\right]}$ & $\begin{array}{c}\mathbf{d} /{ }_{s c} / \mathbf{d} T \\
{\left[\mathrm{~mA} / \mathrm{cm}^{2} / \mathrm{K}\right]}\end{array}$ & $\begin{array}{c}\mathbf{d} / I_{m p} / \mathbf{d} T \\
{\left[\mathrm{~mA} / \mathrm{cm}^{2} / \mathrm{K}\right]}\end{array}$ & $\begin{array}{l}\mathbf{d} V_{m p} / \mathbf{d} T \\
\left(\mathbf{m V} /{ }^{\circ} \mathbf{C}\right]\end{array}$ & $\begin{array}{l}\mathbf{d} V_{o C} / \mathbf{d} T \\
\left(\mathbf{m V} /{ }^{\circ} \mathbf{C}\right]\end{array}$ & $\begin{array}{l}\text { Cell Area } \\
\text { [cm²] }\end{array}$ \\
\hline 2.277 & 2.565 & 0.016 & 0.0168 & 0.01 & 0.009 & -6.01 & -6 & 26 \\
\hline
\end{tabular}

\section{SOLAR ARRAY POWER REQUIREMENTS AND DEGRADATION FACTORS}

The required power for the satellite during the mission is obtained from the power consumption of all satellite subsystems, such as attitude and orbit control subsystem (AOCS), on board data handling subsystem (OBDH), telemetry, command and ranging subsystem (TC\&R), propulsion, thermal control, etc., including, the harness loss, battery charging and power condition unit (PCU) consumption.

In this paper, the highest power demand at the EOL is $2200 \mathrm{~W}$ at equinox. This will be the power requirement used to calculate and determine the power generated by the solar arrays at the BOL. The power needed at BOL was $2337.5 \mathrm{~W}$.

The degradation factors, which used to calculate the output power, are listed in Table 4 . At the BOL, the degradation factors are mainly caused by external factors, such as assembly mismatch loses or some performance reductions due to the coating of the cover glass. At the end of the mission life, there are several factors that affect the performance of a regular solar cell; these factors could affect the voltage or current characteristics of the cells, and are mainly related to space environmental factors across the mission life cycle. 
Table 4. Degradation factors at BOL and EOL.

\begin{tabular}{|l|c|c|c|}
\hline & & Assembly mismatch loss & 0.98 \\
\hline Degradation factors at BOL & Affecting I & 0.98 \\
\hline & & Coverglass coating & 0.96 \\
\hline & & Total & 0.99 \\
\hline & & Coverglass charge particles & 0.97 \\
\hline \multirow{2}{*}{ Degradation factors at EOL } & Current Factors & Ultraviolet rays & 0.98 \\
\hline & & Propellant contamination & 0.98 \\
\hline & & Micrometeoroid damage & 0.92 \\
\hline
\end{tabular}

\section{SOLAR PANEL POWER GENERATION}

\section{Solar cell equivalent circuit models}

Several equivalent circuits for the solar cell characteristics analysis have been proposed in the literature, but only two models are used practically. In this section the five common models are briefly presented (Cubas et al. 2017; Rekioua and Matagne 2012; AlRashidi et al. 2013; Jena and Ramana 2015; Humada et al. 2016; Harrag and Messalti 2015). The equivalent circuit consists of a current source with single, double or triple diode connected in parallel, and up to two resistors, one connected in parallel and the other one in series, to take into account energy losses in this model. Based on these electronic components, five basic configurations are normally used when studying photovoltaic systems are shown in Fig. 3 (Cubas et al. 2017). These models differ in the calculation procedure, accuracy and the number of parameters involved in the calculation of the current-voltage characteristic (Rekioua and Matagne 2012).

(a)

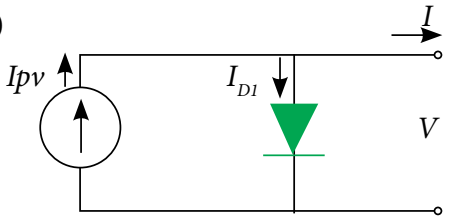

(b)

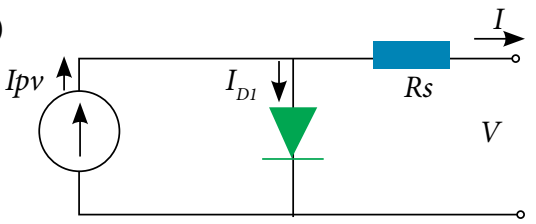

(c)

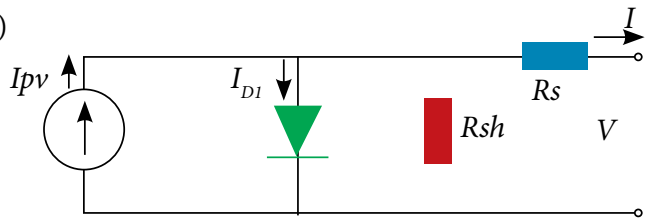

(d)

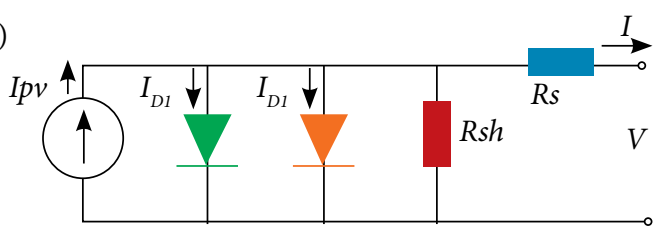

(e)

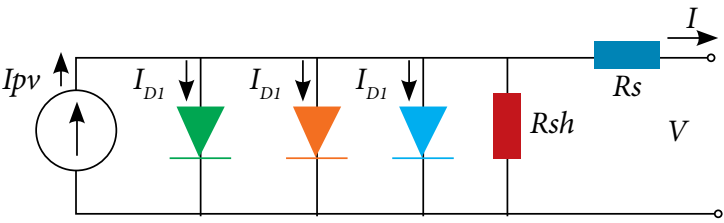

Figure 3. Five different equivalent circuit models. (a) Single diode; (b) Single diode with one resistor; (c) single diode with two resistors; (d) double diode with two resistors; (e) triple diode with two resistors.

a) The single diode model

In Fig. 3a, the equation to relate the output current, $I$, to the output voltage, $V$, is given by Eq. 1 : 


$$
I=I_{p v}-I_{D 1}=I_{p v}-I_{0}\left[\exp \left(\frac{V}{N_{a} V_{T}}\right)-1\right]
$$

where $I_{p v}$ is the photocurrent delivered by the constant current source, $I_{0}$ is the reverse saturation current corresponding to the diode, $V_{T}$ is the thermal voltage ( $V_{T}=k T / q$, where $k$ is the Boltzmann constant, $T$ the temperature expressed in Kelvin, and $q$ is the electron charge), $a$ is the ideality factor that takes into account the deviation of the diodes from the Shockley diffusion theory, and $\mathrm{N}$ is the number of series-connected cells in the photovoltaic system to be analyzed (obviously, $N=1$ in case of a single cell) (Cubas et al. 2017).

b) The single diode with one resistor model. The main equation of Fig. $3 \mathrm{~b}$ is given by Eq. 2 :

$$
I=I_{p v}-I_{0}\left[\exp \left(\frac{V+I R_{S}}{N_{a} V_{T}}\right)-1\right]
$$

Where $R_{s}$ is the series resistor.

c) The single diode with two resistor model

The main equation of the model in Fig. $3 \mathrm{c}$ is given by Eq. 3:

$$
I=I_{p v}-I_{0}\left[\exp \left(\frac{V+I R_{S}}{N_{a} V_{T}}\right)-1\right]-\frac{V+I R_{S}}{R_{s h}}
$$

Where $R_{s h}$ is the shunt resistor.

d) The double diode with two resistors model

The main equation of the model in Fig. $3 \mathrm{~d}$ is expressed by Eq. 4:

$$
I=I_{p v}-I_{01}\left[\exp \left(\frac{V+I R_{S}}{N_{a 1} V_{T}}\right)-1\right]-I_{02}\left[\exp \left(\frac{V+I R_{S}}{N_{a 2} V_{T}}\right)-1\right]-\frac{V+I R_{S}}{R_{S h}}
$$

e) The triple diode with two resistors model:

The main equation of the model in Fig. 3e is given by Eq. 5:

$$
I=I_{p v}-I_{01}\left[\exp \left(\frac{V+I R_{S}}{N_{a 1} V_{T}}\right)-1\right]-I_{02}\left[\exp \left(\frac{V+I R_{S}}{N_{a 2} V_{T}}\right)-1\right]-I_{03}\left[\exp \left(\frac{V+I R_{S}}{N_{a 3} V_{T}}\right)-1\right]-\frac{V+I R_{S}}{R_{S h}}
$$

In the triple diode model, the first diode would contribute the diode current $\left(I_{D 1}\right)$ due to diffusion and recombination in the quasi neutral regions of the emitter and bulk regions with $N_{a 1}=1$, and the second diode would contribute the diode current $\left(I_{D 2}\right)$ due to recombination in the space charge region with $N_{a 2}=2$. The purpose of adding a third diode in parallel to the two diodes is to consider contribution of the diode current component $\left(I_{D 3}\right)$, due to recombination in the defect regions, grain sites, etc. The ideality factor $N_{a 3}$, of the third diode is to be estimated along with other parameters of the model and is predicted to be varying between 2 and 5 depending on the local factors (Steingrube et al. 2011; Khanna et al. 2015).

\section{SELECTED MODEL}

An analytical approach is introduced to investigate the electrical behavior of solar panels. It considers all effective parameters in designing solar arrays for space applications.

In order to reduce complexity, single diode model is selected for modeling the solar cell. Figure $3 \mathrm{c}$ shows the equivalent circuit of one-diode model of a solar cell. This model, used by several researchers, have been used for the simulation. The use of this single diode model to describe the static $I-V$ characteristic has been widely considered, it has been successfully used to fit experimental data and offers good compromise between approximation precision and simplicity (Bouzidi et al. 2012; Lotsch et al. 2005).

The current-voltage characteristic of the model is also based on Eq. 3 and is represented by Eqs. 6-8: 


$$
\begin{gathered}
I_{o p}=I_{s c} A_{c e l l} N_{p}\left\{1-A_{2}\left[\exp ^{-\left[\frac{V_{o p}}{A_{1} V_{o c} N_{S}}\right]}-1\right]\right\} \\
A_{1}=\frac{\frac{V_{m p}}{V_{o c}}-1}{\ln \left(1-\frac{I_{m p}}{I_{s c}}\right)} \\
A_{2}=\left(1-\frac{I_{m p}}{I_{S C}}\right) \exp ^{-\left(\frac{V_{m p}}{A_{1} V_{o c}}\right)}
\end{gathered}
$$

Where: $A_{\text {cell }}$ : cell area, $N_{p}$ : number of cells in parallel, $N_{s}$ : number of cells in serial, $I_{s c}:$ short circuit current, $I_{m p}:$ current at maximum power point, $V_{m p}$ : voltage of maximum power point, $V_{o c}$ : open circuit voltage, $V_{o p}:$ operation voltage, $I_{o p}$ : operation current.

Once the variables $V_{m p}, V_{o c} I_{m p}$ and $I_{s c}$ have been supplemented with the corresponding temperature coefficients and the radiation dependent on the remaining factors $R$ as shown in the following example for $A_{1}$ (Eqs. 9-12), one obtains the temperature and radiation dependent $I-V$ characteristic of the solar array (Ley et al. 2009):

$$
\begin{gathered}
V_{m p}(T, R)=V_{m p}\left(T_{0}\right) R\left(V_{m p}\right)+\frac{d V_{m p}}{d T}\left(T-T_{0}\right) \\
V_{o c}(T, R)=V_{o c}\left(T_{0}\right) R\left(V_{o c}\right)+\frac{d V_{o c}}{d T}\left(T-T_{0}\right) \\
I_{m p}(T, R)=I_{m p}\left(T_{0}\right) R\left(I_{m p}\right)+\frac{d I_{m p}}{d T}\left(T-T_{0}\right) \\
I_{s c}(T, R)=I_{s c}\left(T_{0}\right) R\left(I_{s c}\right)+\frac{d I_{s c}}{d T}\left(T-T_{0}\right)
\end{gathered}
$$

where $T$ is cell temperature and $T_{0}$ cell normal temperature $28^{\circ} \mathrm{C}$.

Eq. 13 and Eq.14, which depends on temperature, are given by:

$$
\begin{gathered}
A_{3}=\frac{\frac{V_{m p}(T, R)}{V_{o c}(T, R)}-1}{\ln \left[1-\frac{I_{m p}(T, R)}{I_{S c}(T, R)}\right]} \\
A_{4}=\left(1-\frac{I_{m p}(T, R)}{I_{S c}(T, R)}\right) \exp ^{-\left(\frac{V_{m p}(T, R)}{A_{3} V_{o c}(T, R)}\right)}
\end{gathered}
$$

Figure 4 shows that solar cells on the array are segmented in many strings connected in parallel. The following relations (Eqs. 15-16) approximately hold true with a suitable margin in the array segmentation. The margin varies as the design progresses from the conceptual stage to the final design (Ley et al. 2009). 


$$
\begin{gathered}
N_{\text {CellsperString }}=\frac{V_{S A}}{V_{W P}} \\
N_{\text {StringsperSection }}=\frac{I_{S}}{I_{W P}}
\end{gathered}
$$

where $V_{S A}$ is solar array voltage, $V_{W P}$ is working point voltage, $I_{S}$ Seat current per section and $I_{W P}$ is working point current.

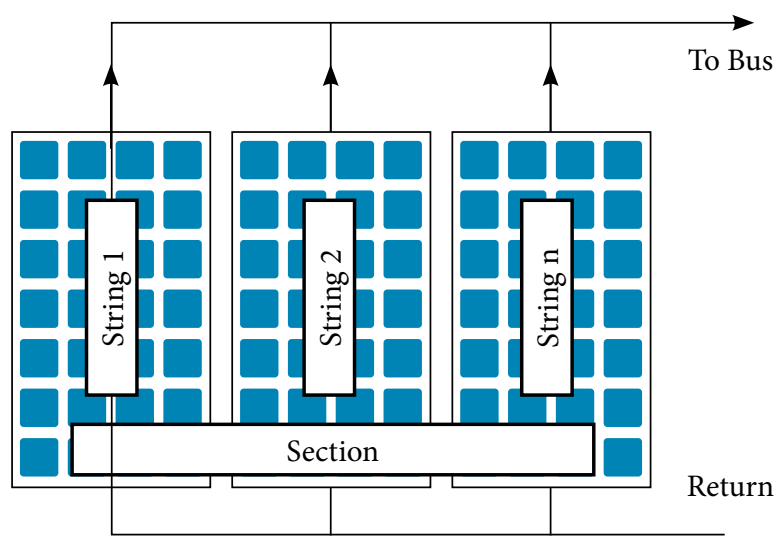

Figure 4. Solar array architecture.

The equation for the $I-V$ characteristic may then be written as Eq. 17:

$$
I_{o p}(T, R)=I_{s c}(T, R) A_{c e l l} N_{p}\left\langle 1-A_{3}(T, R)\left\{\exp ^{\left[\frac{V_{o p}}{A_{4} V_{o c}(T, R) N_{S}}\right]}-1\right\}\right\rangle
$$

The $I-V$ characteristic of a cell irradiated with a certain dose of $1 \mathrm{MeV}$ is achieved by applying the remaining factors $K$ on the cell data (Taherbaneh et al. 2011) (Eqs. 18-21).

$$
\begin{gathered}
V_{m p}(\Phi)=K\left(V_{m p}\right) V_{m p} \\
V_{o c}(\Phi)=K\left(V_{o c}\right) V_{o c} \\
I_{m p}(\Phi)=K\left(I_{m p}\right) I_{m p} \\
I_{S C}(\Phi)=K\left(I_{s c}\right) I_{S c}
\end{gathered}
$$

The generated electrical power of the array for summer solstice after 15 years of in-orbit operation and respecting the degradation factors is calculated as follows (Eq. 22) (Ley et al. 2009):

$$
P=V_{o p} I_{o p} K_{C G} K_{C M} K_{P C}(1-D / Y)^{t}(S I V)
$$


where $P$ : generated electrical power, $I_{o p}$ is operational current, $V_{o p}$ is operational voltage, $K_{C G}$ is cell cover glass loss factor, $K_{C M}$ is cell mismatch loss factor, $K_{P C}$ is parameter calibration loss factor, $D$ is degradation, $Y$ is year, $t$ is satellite life and $S I V$ is seasonal solar intensity variations.

Note that Eqs. 6 and 22 are used in the expression of objective functions for simulation in the GSA algorithm. The main parameters to optimize in this study using the multiobjective GSA algorithm are mainly the following: number of cells in serial $\left(N_{s}\right)$, number of cells in parallel $\left(N_{p}\right)$, bus current $I_{o p}$, bus voltage $\left(V_{o p}\right)$, bus power $(P)$ and temperature $(T)$. All these constitute the individual position of several masses that represent a complete solution set. The initial positions of each agent should be randomly selected while satisfying different equality and inequality constraints of the geostationary communication satellite solar array optimization.

\section{A MULTIOBJECTIVE GRAVITATIONAL SEARCH ALGORITHM}

In solving optimization problems with a large search space, conventional optimization algorithms do not provide an appropriate solution, as the search space increases exponentially with the size of the problem, thus solving problems exact techniques (such as exhaustive search) are not practical.

In this paper, the studied algorithm called gravitational search algorithm (GSA) is based on the law of gravity and the notion of interactions between point masses. The GSA algorithm uses the theory of Newtonian physics and its search agents are a collection of masses. Gravitational force is a way of transferring information between different masses, as any other algorithm based on a population (Esmat et al. 2009; Ghalambaz et al. 2011; Chatterjee et al. 2010; Khajehzadeh and Eslami 2012; Siddique and Adeli 2016; Ghazali et al. 2017).

The multiobjective GSA algorithm is shown in Fig. 5. Every mass accelerates along a resulting force from neighboring masses. The agents are considered objects and their performance is measured by their masses. All these objects attract each other by the force of gravity, and this force causes a global movement of all objects towards objects with heavier masses. Therefore, the masses cooperate by using a direct form of communication, by the gravitational force. The heavy masses - which correspond to the good solutions - move more slowly than the lighter ones, which guarantees the exploitation step of the algorithm (Bohat and Arya 2018).

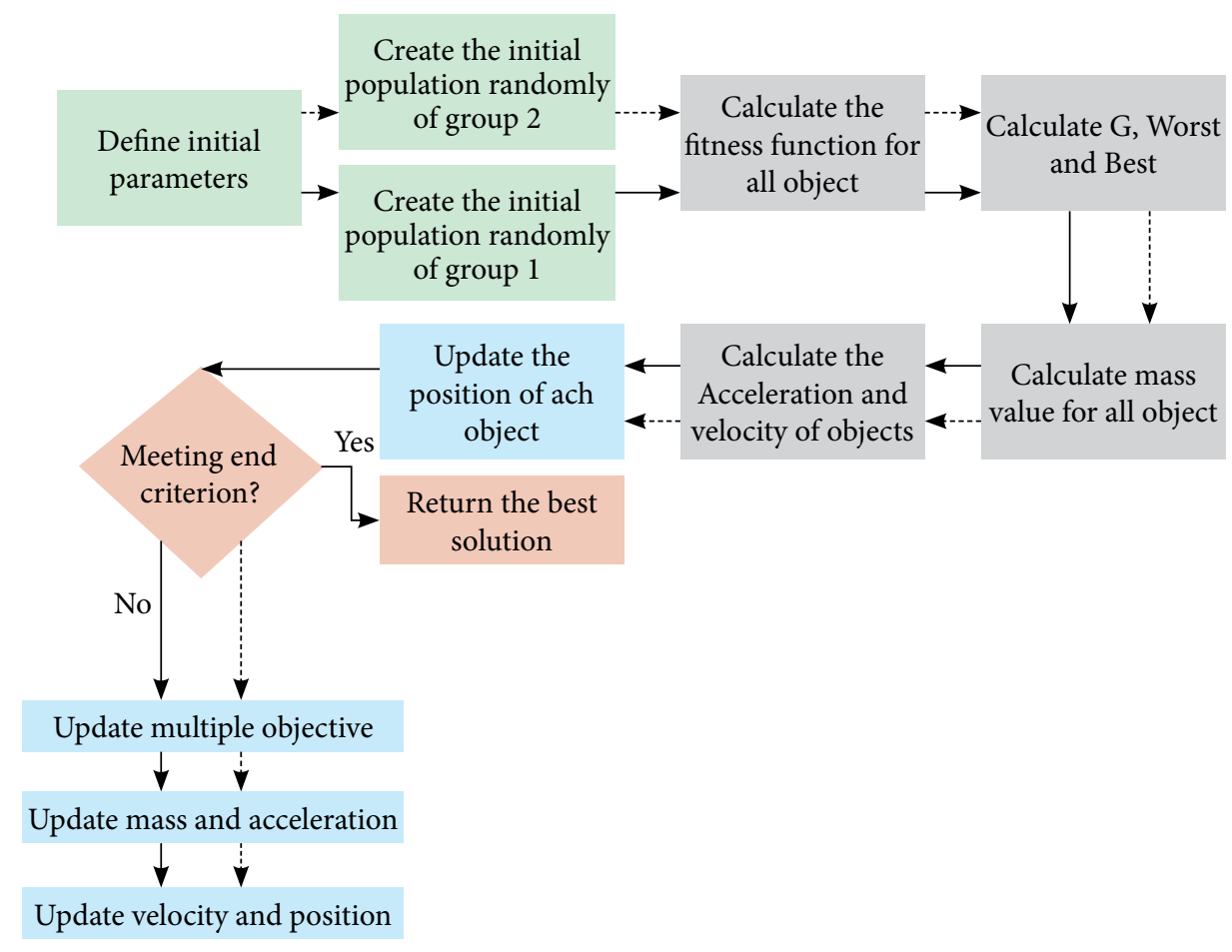

Figure 5. Multiobjective GSA algorithm flowchart. 
In GSA, each mass (agent) has four specifications: position, inertial mass, active gravitational mass, and passive gravitational. The mass position and its gravitational and inertial masses are determined using an objective function. In other words, each mass presents a solution, and the algorithm is navigated by correctly adjusting gravity and mass of inertia. Over time, the masses are expected to be attracted by the heavier mass (Oliveira et al. 2018). As shown in Fig. 6 every mass accelerates toward a resultant force combining effects of all masses.

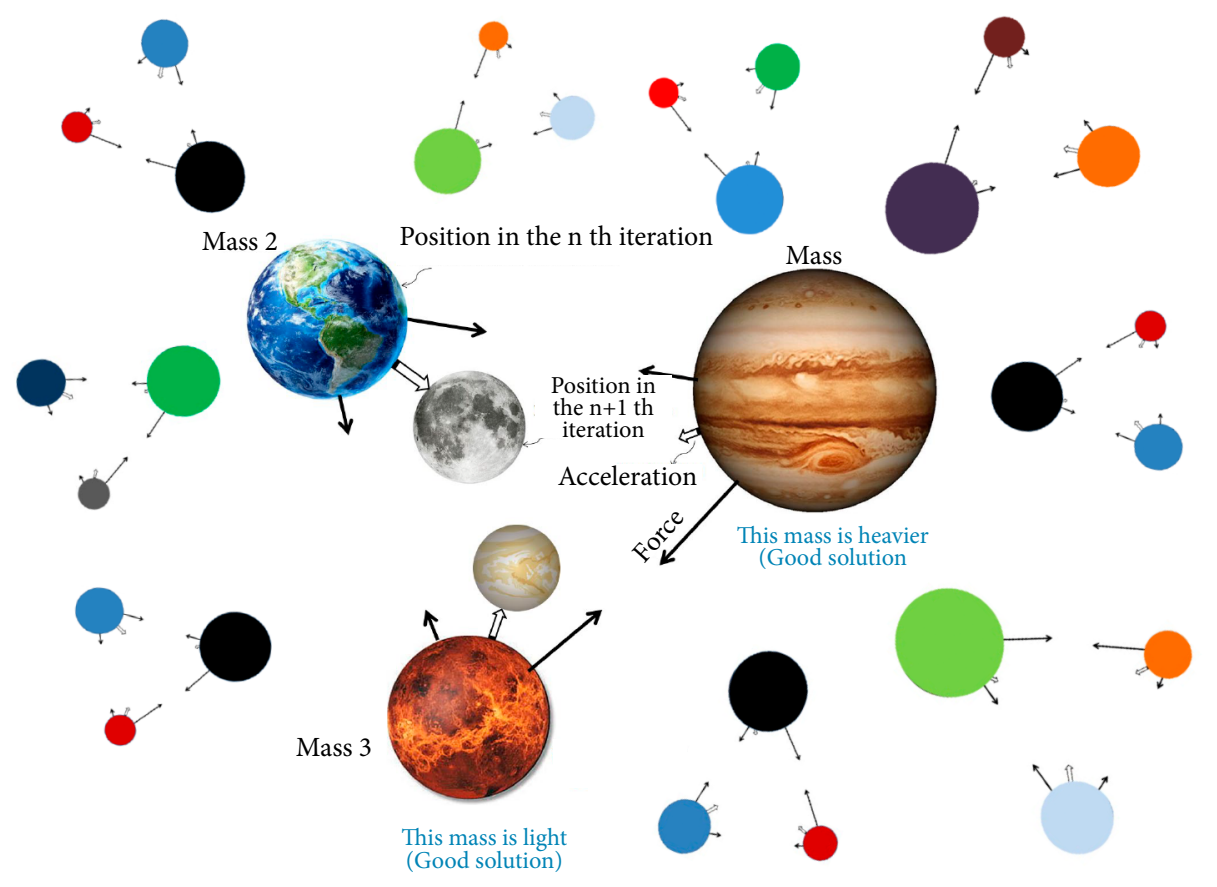

Figure 6. Gravitational forces between particles concept.

For the use of the GSA algorithm in the case of multiobjective functions, modifications have been made according to the research work of Hassanzadeh and Rouhani (2010). Several authors have based their research work on the multiobjective GSA for numerous applications (Ghasemi et al. 2013; Mondal et al. 2013; Tian et al. 2014). The force acting on mass $i$ from mass $j$, which depend on time $t$, is given by Eq. 23:

$$
F_{i j}^{d}=G_{0} \exp \left(-\alpha \frac{t}{T}\right)\left(\frac{M_{j}^{k}}{R_{i j}(t)+\varepsilon}\right)\left(x_{j}^{d}(t)-x_{i}^{d}(t)\right)
$$

where $M_{i}$ is the gravitational mass related to agent $i ; M_{i}$ is the gravitational mass related to agent $j ; \varepsilon$ is small constant; $R_{i j}$ is the Euclidean distance between the two agents $i$ and $j$; $G_{0}$ is the initial value of $G$; T is the total number of iterations and $\alpha$ is the parameter.

The acceleration of the agent $i$ at time $t$ and in direction $d^{\text {th }}$, is given by Eq. 24, where $M_{i j}$ is the inertial mass of the $i^{\text {th }}$ agent (Bohat and Arya 2018).

$$
a_{i}^{d}(t)=\frac{F_{i}^{d}(t)}{M_{i j}(t)}
$$


The position of every agent is defined as:

$$
\begin{gathered}
X_{i}=X_{i}^{1}, \ldots X_{i}^{n}, \ldots X_{i}^{d i m} \\
i=1,2, \ldots, N
\end{gathered}
$$

Where $X_{j}^{1}$ the position of $i^{\text {th }}$ agent is in $n^{\text {th }}$ dimension, $N$ is number of agents in the search space and $d i m$ is prespecified dimension of the problem (Bohat and Arya 2018).

The fitness evaluation of current population of agents performed through considered objective function followed by the calculation of masses of all agents as shown in Eq. 26 and 27:

$$
\begin{gathered}
m_{i}(t)=\frac{{\text { fitness }\left(X_{i}^{k}\right) \text {-worst }}^{k}}{\text { best }^{k}-\text { worst }^{k}} \\
i=1,2,3, \ldots, N \\
M_{i}(t)=\sum_{k=1}^{m} \frac{{\text { fitness }\left(X_{i}^{k}\right)-\text { worst }^{k}}_{\text {best }^{k}-\text { worst }^{k}}}{}
\end{gathered}
$$

where: $M_{i}(t)$ is the gravitational mass related to agent $I$ at iteration $t$; fitness $\left(X_{j}^{k}\right)$ is the evaluation function of the $X_{j}^{k}$, best $t^{k}$ is the the maximum fitness values among the solutions for $k^{\text {th }}$ objective; worst $t^{k}$ is the the minimum fitness values among the solutions for $k^{\text {th }}$ objective and $m$ is the number of objectives functions.

For a minimization problem, the $b e s t^{k}(t)$ and worst $^{k}(t)$ are defined in Eqs. 28 and 29:

$$
\begin{gathered}
\text { best }^{k}=\min _{j \in\{1, \ldots \ldots, N\}} \text { fitness }\left(X_{j}^{k}\right) \\
\text { Worst }^{k}=\max _{j \in\{1, \ldots \ldots, N\}} \text { fitness }\left(X_{j}^{k}\right)
\end{gathered}
$$

\section{MULTIOBJECTIVES FUNCTIONS}

The employment of the GSA algorithm follows a very simple iterative technique to minimize an objectives function, given by $P$ and $I$. The details of this objectives function will be explained later. The design variables are represented by $P$ and $I$ (Eqs. 30 and 31 ).

$$
\begin{gathered}
I_{o p}(T, R)=\left\{N_{s}, N_{p}, V_{o p}, T\right\} \\
P=\left\{N_{s}, N_{p}, V_{o p}, I_{o p}, T\right\}
\end{gathered}
$$

where:

$$
P=V_{o p} I_{S C}(T, R) A_{c e l l} N_{p}\left\langle 1-A_{3}(T, R)\left\{e^{\left[\frac{V_{o p}}{A_{4} V_{o c}(T, R) N_{S}}\right]}-1\right\}\right\rangle K_{C G} K_{C M} K_{P C}(1-D / Y)^{t}(S I V)
$$


To apply the GSA, random values are taken for the design variables within the following ranges. These ranges were chosen based on the minimum size constraints and maximum area constraints, in addition to general observation and intuition about the final design's optimal geometry. Table 5 shows the optimal design parameters with variable design parameters.

Table 5. Range of parameters.
$N_{s}$ (cells)
$N_{p}$ (cells)
$V_{o p}(\mathrm{~V})$
$I_{o p}(\mathrm{~A})$

$$
\begin{gathered}
25 \leq \mathrm{N}_{s} \leq 35 \\
85 \leq N_{p} \leq 110 \\
60 \leq V_{o p} \leq 67 \\
I_{o p \min } \leq I_{o p} \leq I_{o p \max }
\end{gathered}
$$

Case of solstice season

Temperature $T$

$\left({ }^{\circ} \mathrm{C}\right)$
BOL

EOL $37 \leq T \leq 40$

$40 \leq T \leq 44$

BOL

$48 \leq T \leq 51$

EOL
$50 \leq T \leq 54$

\section{RESULTS AND DISCUSSION}

Several simulations and analytical calculations have been performed to determine the optimal parameters of the geostationary satellite solar array.

In order to determine the number of cells in parallel and in series, the number of the solar panel sections, and the number of panels needed in the solar array, numerous aspects must take into account the power of the satellite at end of life as well as the various degradation factors caused by the space environment. This first step in designing a solar array is to find the power consumption at the beginning of life. The second step, the $V-I$ characteristics curve in three cases, at the BOL, at BOL with degradation and at EOL with the degradation factors was defined. The same assumption was made for the $P-V$ characteristics curve. For these calculations, some assumptions were taken. The working point of the solar cells at the EOL, at the BOL and the voltage of the solar arrays were assumed.

Also, the interest of this study is to predict the power generation of the geostationary satellite solar array, which subject to space environment and under a number of practical constraints and other cases both solstice (SS) and equinox season (EQX), in order to extract the desired performance parameters using multiobjective functions.

\section{POWER REQUIREMENTS AND DEGRADATION FACTORS CALCULATION}

In fact, the degradation factors presented in Table 4 are used in the TJ GaAs cell characteristic, which makes it possible to calculate the characteristics of a solar cell, at the BOL and EOL. The main characteristics of a TJ GaAs solar cell, at the BOL and EOL including the degradation factors effects, which used to calculate the total output power, are shown in Table 6.

In order to define the number of solar cells and panels needed for the solar array, there are some considerations that were defined in this paper, such as $64 \mathrm{~V}$ is the solar array voltage, the number of sections on the sequential switching shunt regulator is 16 , the working point of the solar cell at BOL and EOL was taken at the $95 \%$ of the maximum work point. Table 7 shows the TJ GaAs Cells Work Point. 
Table 6. TJ-GaAs cell's main characteristics at BOL and EOL.

\begin{tabular}{|c|c|c|c|}
\hline & \multicolumn{3}{|c|}{ TJ-GaAs cell } \\
\hline & BOL & BOL with degradation & EOL With degradation \\
\cline { 2 - 4 }$V_{\mathrm{mp}}(\mathrm{V})$ & 2.277 & 2.277 & 2.254 \\
\hline$V_{\mathrm{oc}}(\mathrm{V})$ & 2.565 & 2.565 & 2.539 \\
\hline$I_{\mathrm{mp}}\left(\mathrm{A} / \mathrm{cm}^{2}\right)$ & 0.016 & 0.016 & 0.014 \\
\hline$I_{\mathrm{sc}}\left(\mathrm{A} / \mathrm{cm}^{2}\right)$ & 0.0168 & 0.0161 & 0.0148 \\
\hline $\mathrm{d} I_{\mathrm{sc}} / \mathrm{d} T\left(\mathrm{~mA} / \mathrm{cm}^{2} / \mathrm{K}\right)$ & 0.01 & 0.01 & 0.014 \\
\hline $\mathrm{d} I_{\mathrm{mp}} / \mathrm{d} T\left(\mathrm{~mA} / \mathrm{cm}^{2} / \mathrm{K}\right)$ & 0.009 & 0.009 & 0.012 \\
\hline $\mathrm{d} V_{\mathrm{mp}} / \mathrm{d} T\left(\mathrm{mV}^{\circ}{ }^{\circ} \mathrm{C}\right)$ & -6.01 & -6.01 & -6.9 \\
\hline $\mathrm{d} V_{\mathrm{oc}} / \mathrm{d} T\left(\mathrm{mV} /{ }^{\circ} \mathrm{C}\right)$ & -6 & -6 & -6.5 \\
\hline $\mathrm{Work} \mathrm{Temperature}\left({ }^{\circ} \mathrm{C}\right)$ & 28 & 28 & 28 \\
\hline $\mathrm{Cell} \mathrm{Area}\left(\mathrm{cm}^{2}\right)$ & 26 & 26 & 26 \\
\hline
\end{tabular}

Table 7. TJ-GaAs cells work point.

\begin{tabular}{|c|c|c|}
\hline & $I_{\text {op }}$ & $V_{\text {op }}$ \\
\hline BOL & 0.3407 & 2.1631 \\
\hline EOL & 0.2981 & 2.1415 \\
\hline
\end{tabular}

\section{TJ GAAS CELL'S I VS V CHARACTERISTICS}

The $V-I$ and $P-V$ characteristics curves in three cases, at the BOL, at BOL with degradation due to assembly and cover glass and at EOL with the degradation factors, as shown in Fig. 7 and Fig. 8, were defined. For these calculations, some assumptions must be taken. The work point of the solar cells at the EOL and at the BOL and the voltage of the solar arrays was assumed. Usually, some references recommend using a voltage working point near to the $95 \%$ of the maximum voltage point. The current-voltage curve, it can be stated that the photovoltaic module is a constant current source at lower values of voltage with current equal to the short- circuit current $I_{s c}$. With further increase in voltage values, the current starts decreasing exponentially at certain point. The value of current becomes zero at open-circuit voltage $\left(V_{o c}\right)$. In this case, the active surface area is $26 \mathrm{~cm}^{2}$. The point where the module operates at highest efficiency is the maximum power point (MPP), is at $0.94 \mathrm{~W}$.

The nature of PV cell is nonlinear, the output current and power of PV cell depend on the cell's terminal operating voltage, temperature, and solar cells degradation as well with increase of working temperature, the short-circuit current of the PV cell increases, whereas the maximum power output decreases. On the other hand, with increase of mission life of the satellite, the short-circuit current of the PV module decrease, and the maximum power output decrease as well. The reason is the opencircuit voltage is logarithmically dependent on the solar irradiance, yet the short-circuit current is directly proportional to the radiant intensity.

Table 8 gives the number of solar cells, the number of strings on each section, the number of sections per panel and finally the numbers of panels needed in the solar array are calculated. 


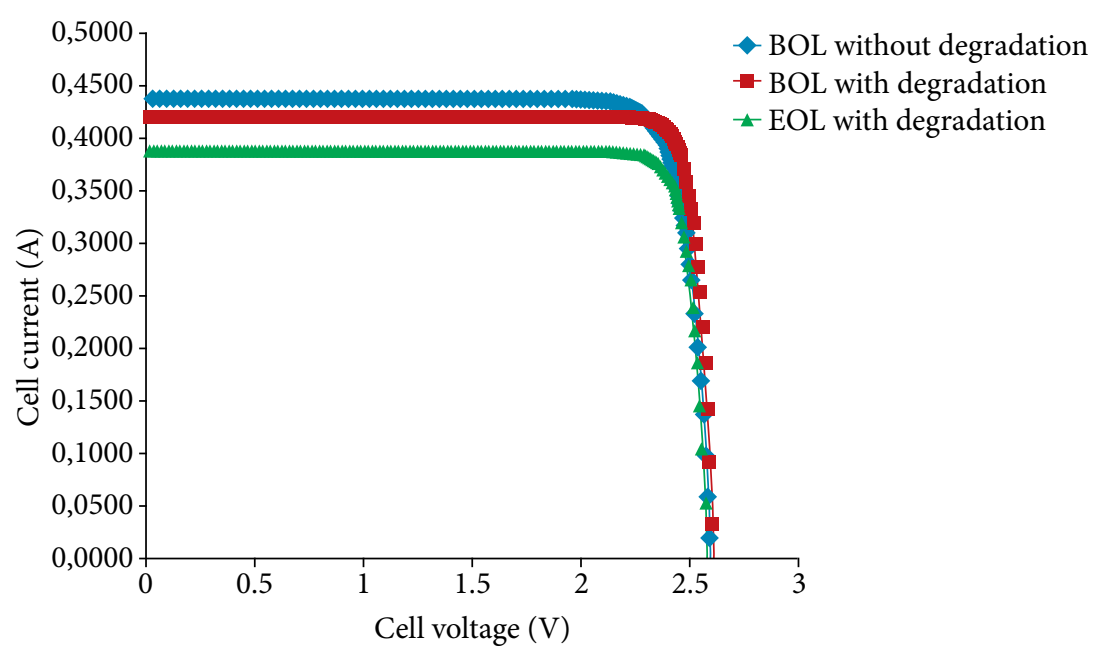

Figure 7. TJ GaAs cell's $I-V$ curve characteristics trough the mission life.

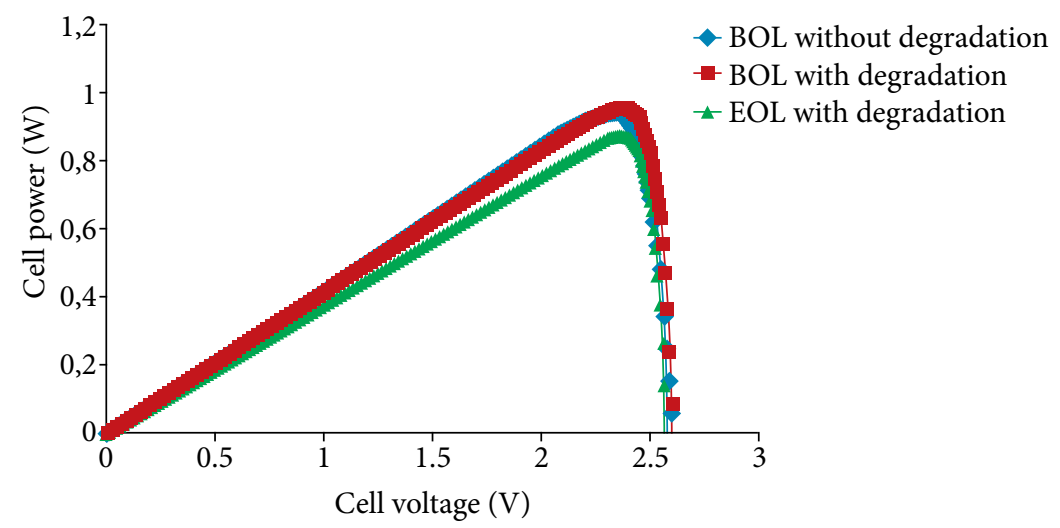

Figure 8. TJ GaAs cell's P-V curve characteristics trough the mission life.

Table 8. Solar array general design.

\section{Number of sections}

Number of strings

Number of cells per string

\section{6}

6

30

\section{OPTIMAL VALUE OF SOLAR POWER GENERATION USING GSA ALGORITHM}

Simulations have been made using the GSA algorithm to analyze different parameters of geostationary communication satellite subsystem solar array. The value of gravitational search algorithm control parameters is given in Table 9. The optimal solutions are obtained after 200 iterations and this after several runs. The optimization process has maximized the power generated, represented by the objective or fitness function $P$, by satisfying the design criteria. The best performing design was saved for each successive starting population to converge on the optimum values. Figs. 9 to 15 , show, this fact by displaying the optimum value of the objective function. The results have been displayed for the following iterations and the optimum values obtained by the GSA algorithm have been described in the Tables 10 and 11. 
Table 9. GSA Control parameters values.

\begin{tabular}{|c|c|}
\hline Number of agents (N) & 200 \\
\hline Max iterations (Max_it) & 200 \\
\hline Parameters values used for algorithm & $\mathrm{G}_{0}=100, \alpha=10$ \\
\hline Mass & Random \\
\hline Velocity & Random \\
\hline Acceleration & Random \\
\hline Position of agents & Random \\
\hline Distance between agents in search space & Random
\end{tabular}

Table 10. Solar array power generation at BOL and EOL.

\begin{tabular}{|c|c|c|c|}
\hline Design variable & BOL & BOL with degradation & EOL with degradation \\
\hline$I_{\mathrm{sc}}\left(\mathrm{A} / \mathrm{cm}^{2}\right)$ & 0.0168 & 0.016134 & 0.014880 \\
\hline$I_{\mathrm{mp}}\left(\mathrm{A} / \mathrm{cm}^{2}\right)$ & 0.016 & 0.016 & 0.014756 \\
\hline$V_{\mathrm{mp}}(\mathrm{V})$ & 2.277 & 2.277 & 2.25423 \\
\hline$V_{\mathrm{oc}}(\mathrm{V})$ & 2.565 & 2.565 & 2.53935 \\
\hline$N p(\mathrm{Cells})$ & 100 & 99 & 99 \\
\hline$N s(\mathrm{Cells})$ & 30 & 28 & 27 \\
\hline$I(\mathrm{~A})$ & 37.43 & 37.14 & 33.94 \\
\hline$V(V)$ & 64.37 & 64.77 & 64.98 \\
\hline$P(W)$ & 2409.34 & 2405.80 & 2205.40 \\
\hline$T\left({ }^{\circ} \mathrm{C}\right)$ & 28 & 28 & 28 \\
\hline
\end{tabular}

Table 11. Solar array power generation at $\mathrm{BOL}$ and $\mathrm{EOL}$ at solstice and equinox season.

\begin{tabular}{|c|c|c|c|c|}
\hline \multirow{2}{*}{} & \multicolumn{3}{|c|}{ BOL } & \multicolumn{2}{c|}{ EOL } \\
\cline { 2 - 5 } & SS & EQX & SS & EQX \\
\hline Temperature & $39^{\circ} \mathrm{C}$ & $49{ }^{\circ} \mathrm{C}$ & $42^{\circ} \mathrm{C}$ & 2182.46 \\
\hline$P(W)$ & 2123.35 & 2398.53 & 1937.80 & 33.68 \\
\hline$I(A)$ & 32.79 & 37.02 & 29.90 & 64.79 \\
\hline
\end{tabular}


Clearly, the GSA algorithm succeeds in progressively finding designs with optimal values of geostationary communication satellite solar array. Additionally, the GSA algorithm appears to converge to the best design. After 200 starting populations of 200 generations have been computed, the five best performing designs are output to the user.

Tables 10 and 11 shows that the design parameters such as the number of cells and temperature mainly affect the value of power generated by solar panel. The solar array current at BOL was $2.283 \mathrm{~A}$ per section and $64 \mathrm{~V}$ voltage level.

Table 10 shows the output power characteristics of the satellite solar array at $28^{\circ} \mathrm{C}$, at $\mathrm{BOL}$ without and with degradation and at EOL. The analytical result of power at $\mathrm{EOL}\left(T=28^{\circ} \mathrm{C}\right)$ is $2386.20 \mathrm{~W}$ and from the results obtained in Table 10 and after optimization, the total power at EOL is decreased by $181 \mathrm{~W}$, one can prove that the relative error is about $8.20 \%$ of the total power. The proposed design, fulfil with all the requirements established for the primary power source defined at the beginning of the paper.

Table 10 shows that the degradation of the solar cells, after 15-years lifetime in orbit is approximately $9 \%$ with power margin of $2.92 \%$ at BOL and $0.24 \%$ at EOL. Table 11 shows the output power prediction of the satellite solar array. Two cases are considered and evaluated, mainly in $\mathrm{BOL}$ and EOL. The first one is in the solstice season at $39^{\circ} \mathrm{C}$ for $\mathrm{BOL}$ and $42^{\circ} \mathrm{C}$ for EOL, and the second case is in the equinox season at $49^{\circ} \mathrm{C}$ for BOL and $52^{\circ} \mathrm{C}$ for EOL.

Clearly, the GSA algorithm succeeds in progressively finding designs with optimal values of geostationary communication satellite solar array. Additionally, the GSA algorithm appears to converge to the best design. After 200 starting populations of 200 generations have been computed, the five best performing designs are output to the user.

From Tables 10 and 11, it is possible to noticed that the design parameters such as the number of cells and temperature mainly affect the value of power generated by solar panel. The solar array current at BOL was $2.283 \mathrm{~A}$ per section and $64 \mathrm{~V}$ voltage level.

According to the results of the simulation in which all the degradation factors of the electrical behavior of the solar panel are taken into consideration during the $\mathrm{BOL}$ and $\mathrm{EOL}$, it is found that the requirements of the mission $P, V$ and $I$ are fulfilled, when the satellite meets different environmental conditions, as shown in Table 11.

Table 12 shows that the designed solar panels satisfy mission power requirements as defined in Table 2.

Table 12. Solar array power requirements and all calculated values at BOL and EOL.

\begin{tabular}{|c|c|c|c|}
\hline & & SS & EQX \\
\hline \multirow{2}{*}{ BOL } & Requirements (W) & 2098 & 2369 \\
\hline & Bus power $(\mathrm{W})$ & 2123 & 2398 \\
\hline \multirow{2}{*}{ EOL } & Requirements (W) & 1913 & 2155 \\
\hline & Bus power $(\mathrm{W})$ & 1937 & 2182 \\
\hline
\end{tabular}

Table 13 shows the power margin between the GSA solar power calculation and mission power requirement, it was taken a margin of $1.19 \%$ in SS season and $1.22 \%$ in EQX season at BOL and $1.25 \%$ in SS season and EQX season at EOL. It shows that the designed GSA calculation results, according to the proposed design, comply with all the requirements established for the primary power source.

Figure 9 shows the variation of current, voltage and power value within the iteration numbers at the beginning of life without degradation at $28^{\circ} \mathrm{C}$, the results give the maximum value $37.43 \mathrm{~A}, 64.37 \mathrm{~V}$ and $2409.34 \mathrm{~W}$ respectively.

Figures 10 and 11 show the variation of current, voltage, power value and the corresponding number of cells in parallel and in serial, within the iteration numbers at beginning of life with degradation and end of life at $28^{\circ} \mathrm{C}$. The results give the maximum value 37.14 and $33.94 \mathrm{~A}, 64.77$ and $64.98 \mathrm{~V}, 2405.80$ and $2205.40 \mathrm{~W}$, respectively. The predicted number of cells of solar panel is about 99 cells in parallel and 28 cells in serial at BOL with degradation. At EOL, the number of cells decreases and it is about 27 cells, due to the number of cells losses, which is necessary to consider for the worst-case scenario. 
Table 13. Solar array power margin at BOL.

\begin{tabular}{|c|c|c|c|c|}
\hline & & & & Power margin [\%] \\
\hline \multirow{4}{*}{$\mathrm{BOL}$} & \multirow{2}{*}{ SS } & Requirements (W) & 2098 & \multirow{2}{*}{1.19} \\
\hline & & Bus power (W) & 2123 & \\
\hline & \multirow{2}{*}{ EQX } & Requirements (W) & 2369 & \multirow{2}{*}{1.22} \\
\hline & & Bus power $(\mathrm{W})$ & 2398 & \\
\hline \multirow{4}{*}{ EOL } & \multirow{2}{*}{ SS } & Requirements (W) & 1913 & \multirow{2}{*}{1.25} \\
\hline & & Bus power $(\mathrm{W})$ & 1937 & \\
\hline & \multirow{2}{*}{ EQX } & Requirements (W) & 2155 & \multirow{2}{*}{1.25} \\
\hline & & Bus power (W) & 2182 & \\
\hline
\end{tabular}
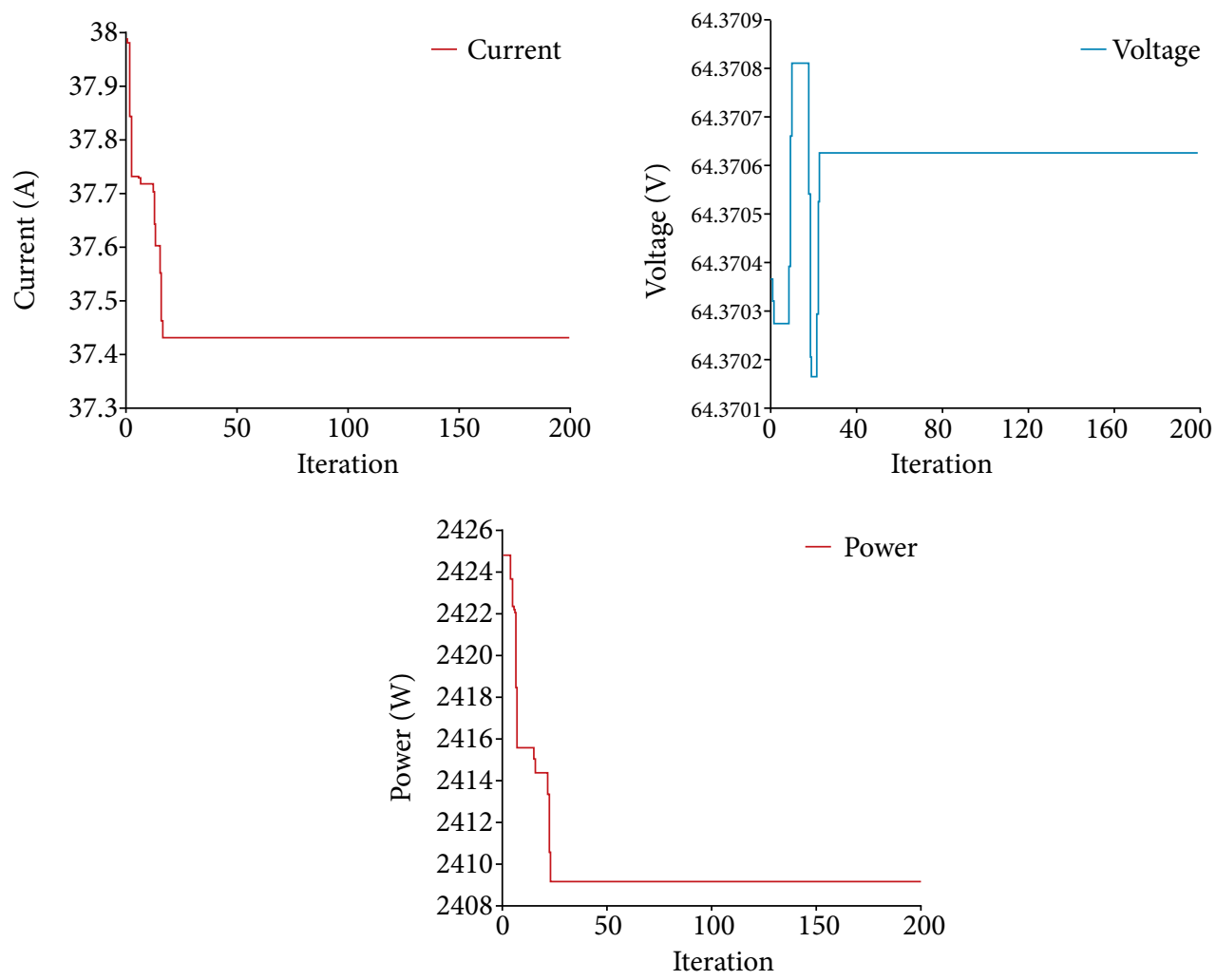

Figure 9. Design variable $I, V$ and $P$ in relation to the iteration numbers at $\mathrm{BOL}$ at $T=28^{\circ} \mathrm{C}$ without degradation.

The power generated by solar panel is mainly depend on several parameters, which correspond to selected model. However, the number of cells in serial and number of cells in parallel are part in the determination of power generation equation as well as the nonlinearity of the model as function of the temperature. 
Figures 12 and 13 show the variation of current voltage and power value within the iteration numbers in the beginning of life at 39 and $49^{\circ} \mathrm{C}$, which gives the maximum value $32.79 \mathrm{~A}, 64.77 \mathrm{~V}$ and $2123.35 \mathrm{~W}$, at solstice season and $37.02 \mathrm{~A}, 64.77 \mathrm{~V}$ and $2398.53 \mathrm{~W}$, at equinox season respectively.

Figures 14 and 15, show the variation of current value within the iteration numbers in the end of life at 42 and $52{ }^{\circ} \mathrm{C}$, wich gives the maxumum value $29.90 \mathrm{~A}, 64.79 \mathrm{~V}$ and $1937.80 \mathrm{~W}$, at solstice season and $33.68 \mathrm{~A}, 64.79 \mathrm{~V}$ and $2182.46 \mathrm{~W}$ at equinox season respectively. It is noticed that the parameters $I, V$ and $P$ vary with the variation of the temperature, the degradation factors as well as during the satellite life cycle, this is due mainly to the nonlinearity of the system.
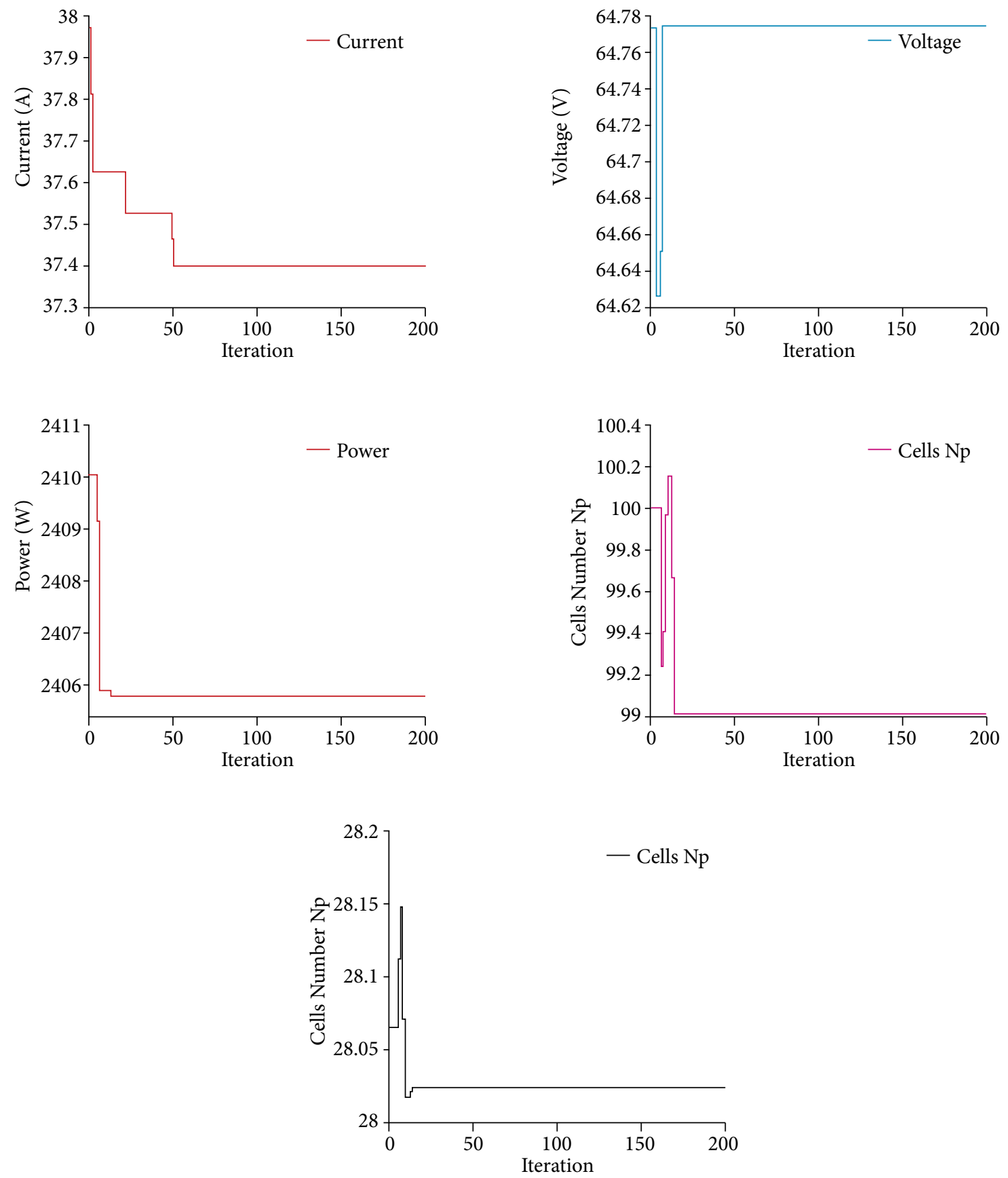

Figure 10. Design variable $I, V, P, N_{p}$ and $N_{s}$ in relation to the iteration numbers at $B O L$ at $T=28{ }^{\circ} \mathrm{C}$ with degradation. 

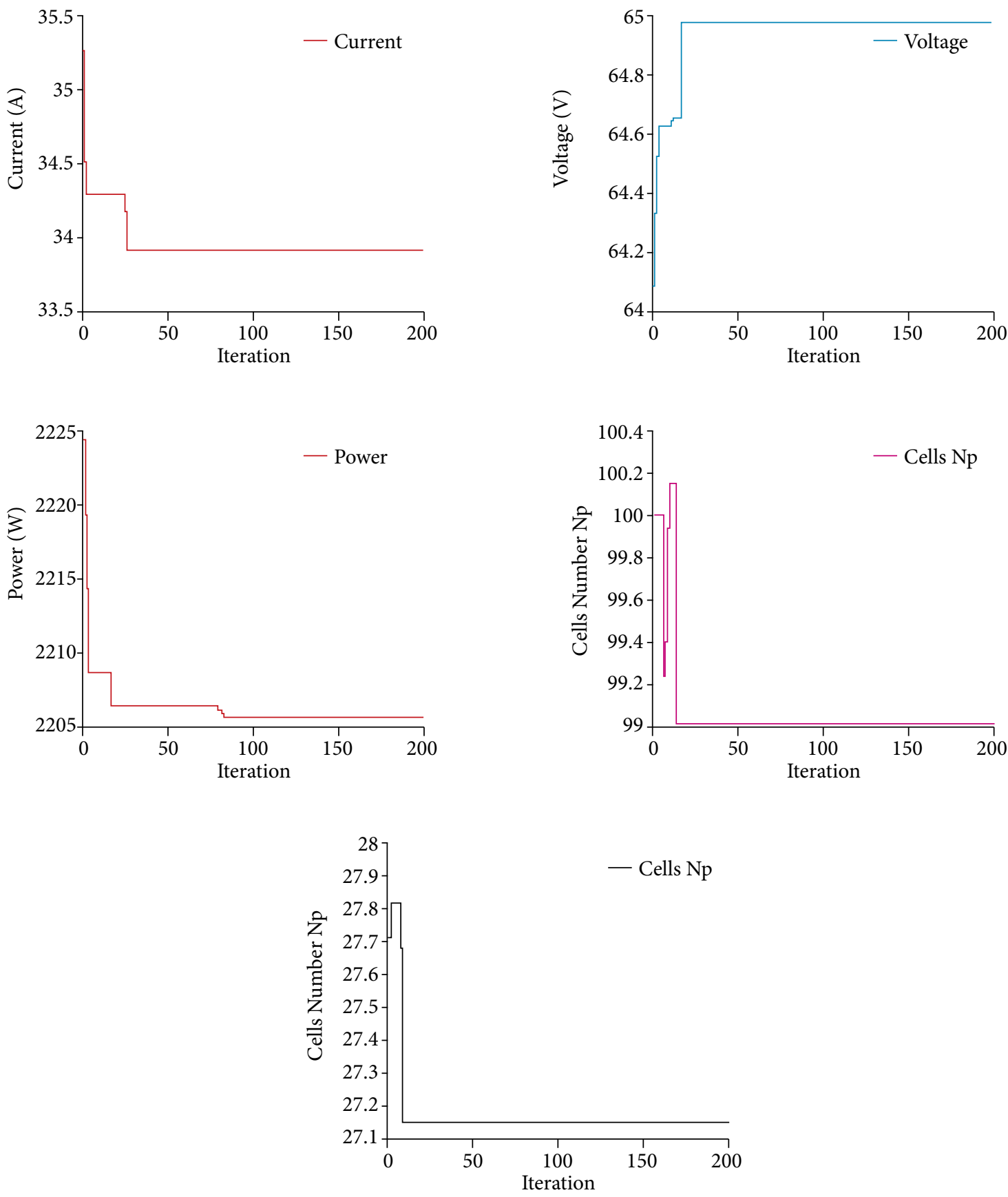

Figure 11. Design variable $I, V, P, N_{p}$ and $N_{s}$ in relation to the iteration numbers at $\mathrm{EOL}$ at $T=28{ }^{\circ} \mathrm{C}$ with degradation.

From Fig. 16, the result of GSA was compared with results obtained from the genetic algorithm (GA) at the EOL in the case of $28^{\circ} \mathrm{C}$. The obtained results clearly reveal that GSA algorithm can provide accurate optimized values with a smaller number of iterations. The best value of solar array power at EOL is $2205.4 \mathrm{~W}$ was obtained by GSA and comply with the requirement compared with the value of GA, which is $2205.58 \mathrm{~W}$. Therefore, the GSA can be recommended as the best optimization algorithm for parameter estimation of satellite solar array. 
Geostationary Communication Satellite Solar Array Optimization Using Gravitation Search Algorithm

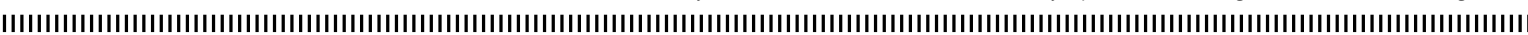
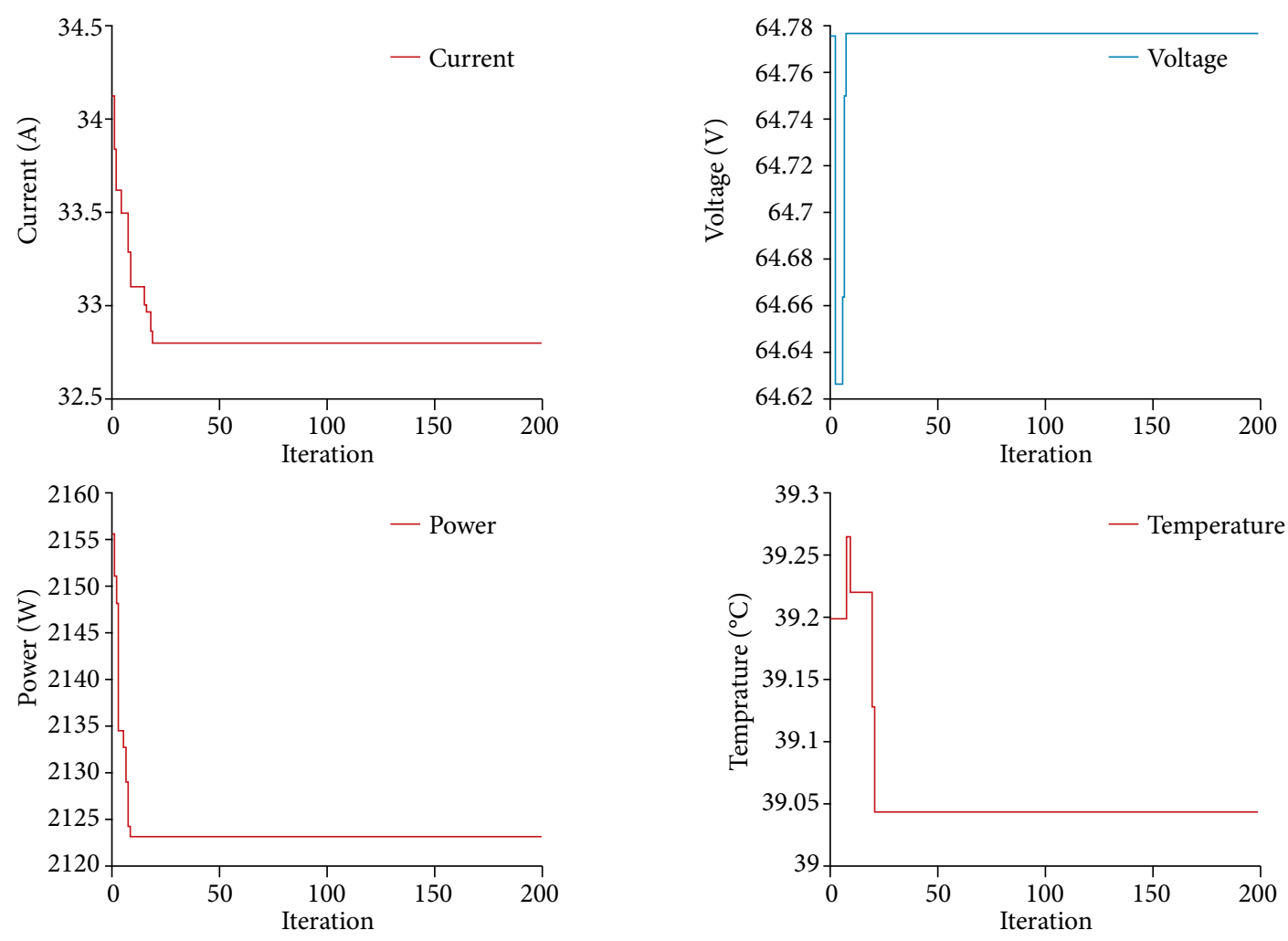

Figure 12. Design variable $I, V, P$ and $T$ in relation to the iteration numbers at $\mathrm{BOL}$ in solstice season at $T=39{ }^{\circ} \mathrm{C}$.
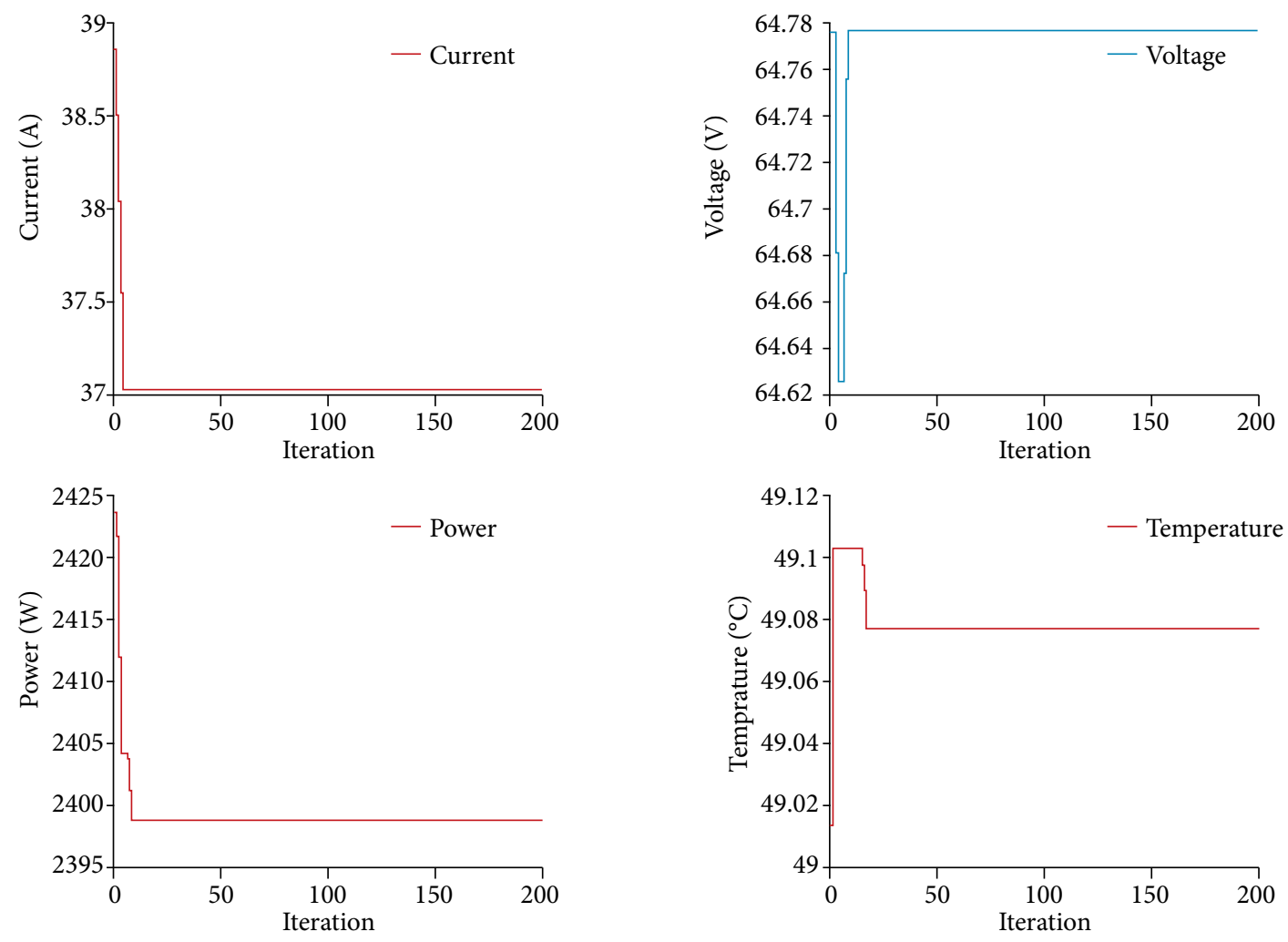

Figure 13. Design variable $I, V, P$ and $T$ in relation to the iteration numbers at $\mathrm{BOL}$ in equinox season at $T=49^{\circ} \mathrm{C}$. 

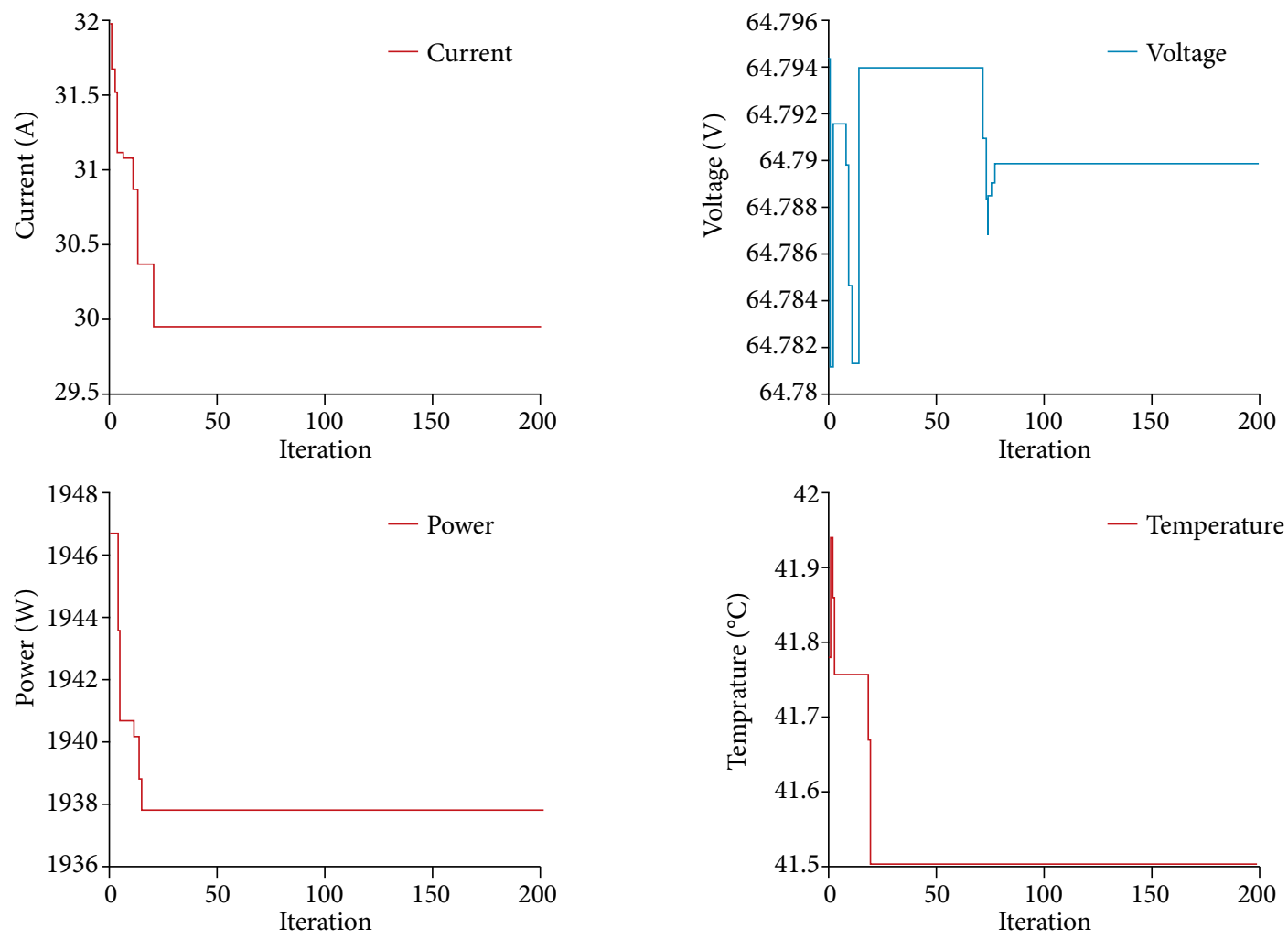

Figure 14. Design variable $I, V, P$ and $T$ in relation to the iteration numbers at EOL in solstice season at $T=42{ }^{\circ} \mathrm{C}$.
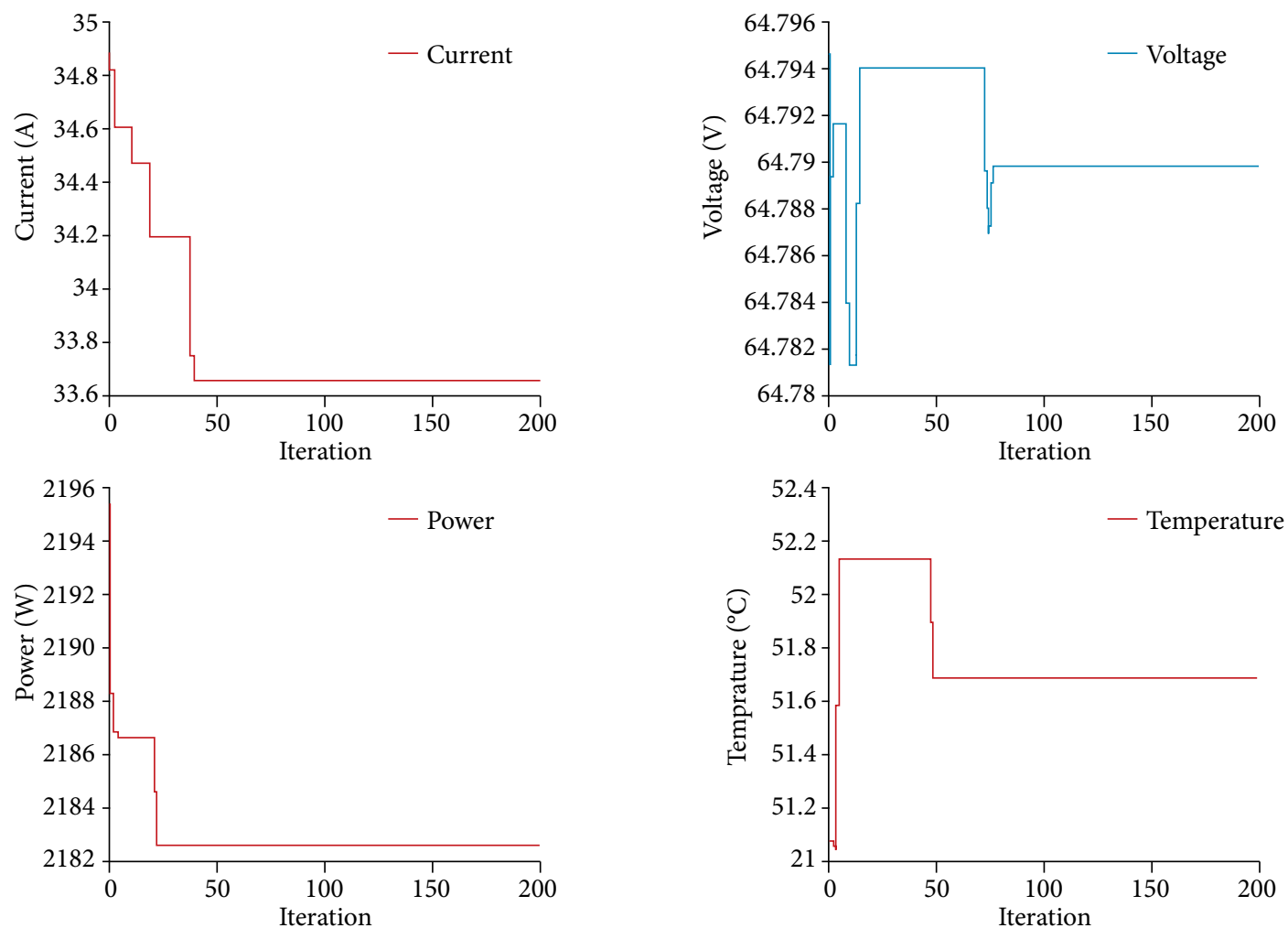

Figure 15. Design variable $I, V, P$ and $T$ in relation to the iteration numbers at EOL in equinox season at $T=52{ }^{\circ} \mathrm{C}$. 


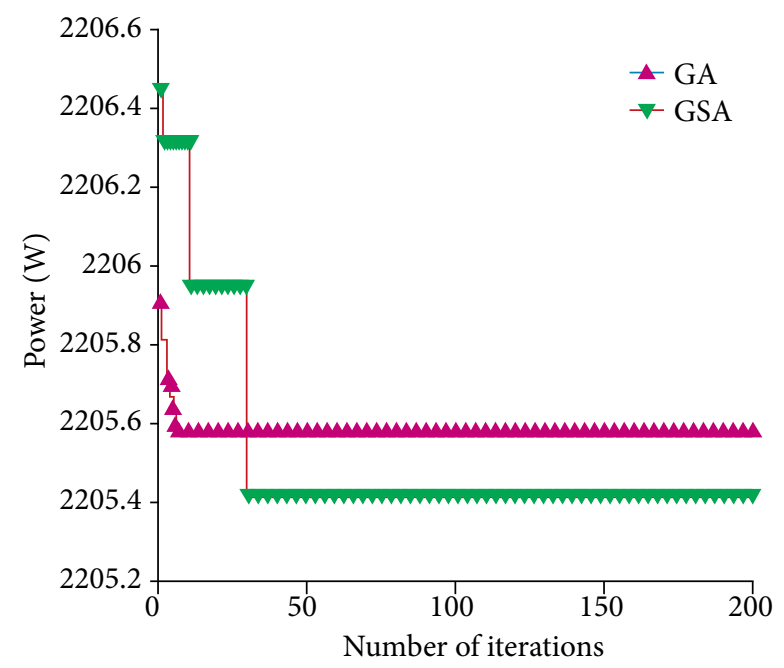

Figure 16. Convergence characteristics of GSA and GA.

\section{CONCLUSION}

In this research, design of a solar array and its necessary considerations for a space mission were presented. The designed solar array, which should supply the required power for the mentioned mission, was consisted of two equal solar panels. Each panel consisted of six strings, which were made of thirty series triple-junction GaAs solar cells.

In this paper, the GSA was proposed to optimize simultaneously multiple objectives functions for solving the geostationary solar array problem. Optimal operation of a power system is one of the most important aspects of the power subsystem. The GSA optimization algorithm is used as a tool for the extraction of the solar array parameters in which all the degradation factors of the electrical behavior of the solar panel are taken into consideration during the BOL and EOL. As it was shown, the effectiveness of the suggested algorithm verified on several test cases (on solstice and equinox seasons).

It was observed from the results that the optimization process is highly essential to achieve a better design with better performance parameters for the geostationary solar array.

The results show that the design parameters such as the number of cells in serial, number of cells in parallel and temperature, mainly affect the value of power generated by solar panel at EOL. However, the total power of the optimized system is decreased by $181 \mathrm{~W}$ (i.e., $8.20 \%$ of the total power). The corresponding of optimized value of current and voltage generated by solar panel were found at $33.94 \mathrm{~A}$ and $64.98 \mathrm{~V}$, respectively. The degradation and output power characteristics of the solar panels were calculated for different temperature values. The active surface area is $26 \mathrm{~cm}^{2}$. The maximum power point is at $0.94 \mathrm{~W}$.

The results are in full accordance with the mission requirements either in beginning or in end of life. The degradation and output power characteristics of the solar panels were calculated for different temperature values. Therefore, the power prediction of the designed solar array for the mentioned satellite completely satisfies its mission requirements.

\section{ACKNOWLEDGMENTS}

The authors would like to thank the Algerian Space Agency and the Centre of Satellites Development for their support of this research.

Editors and authors are thankful to Fundação Conrado Wessel for providing the financial support for publishing this article. 


\section{AUTHOR'S CONTRIBUTION}

Conceptualization: Oukil S and Boudjemai A; Methodology: Oukil S and Boudjemai A; Investigation: Oukil S and Boudjemai A; Writing - Original Draft: Oukil S; Writing - Review and Editing: Oukil S and Boudjemai A.

\section{REFERENCES}

AlRashidi MR, AlHajri MF, El-Naggar KM, Al-Othman AK (2011) A new estimation approach for determining the $I-V$ characteristics of solar cells. Sol Energy 85(7):1543-1550. https://doi.org/10.1016/j.solener.2011.04.013

AlRashidi MR, El-Naggar KM, AlHajri MF (2013) Parameters estimation of double diode solar cell model. Int J Electr Comput Eng 7(2):118-121. https://doi.org/10.5281/zenodo.1327855

Bhattacharya A, Roy PK (2012) Solution of multi-objective optimal power flow using gravitational search algorithm. IET Gener Transm Distrib 6(8):751-763. https://doi.org/10.1049/iet-gtd.2011.0593

Bohat VK, Arya KV (2018) An effective gbest-guided gravitational search algorithm for real-parameter optimization and its application in training of feedforward neural networks. Knowl-Based Syst 143:192-207. https://doi.org/10.1016/j.knosys.2017.12.017

Bouzidi K, Chegaar M, Aillerie M (2012) Solar cells parameters evaluation from dark I-V characteristics. Energy Procedia 18:1601-1610. https://doi.org/10.1016/j.egypro.2012.06.001

Castañer L, Silvestre S (2002) Modelling photovoltaic systems using PSpice ${ }^{\circledast}$. Hoboken: John Wiley \& Sons. https://doi. org/10.1002/0470855541

Chatterjee A, Mahanti GK, Pathak NN (2010) Comparative performance of gravitational search algorithm and modified particle swarm optimization algorithm for synthesis of thinned scanned concentric ring array antenna. Prog Electromagn Res B 25:331-348. https:// doi.org/10.2528/PIERB10080405

Chegaar M, Ouennoughi Z, Guechi F, Langueur H (2003) Determination of solar cells parameters under illuminated conditions. Journal of Electron Devices 2:17-21.

Cubas J, Pindado S, Victoria M (2014) On the analytical approach for modeling photovoltaic systems behavior. J Power Sources 247:467474. https://doi.org/10.1016/j.jpowsour.2013.09.008

Cubas J, Pindado S, Sorribes-Palmer F (2017) Analytical calculation of photovoltaic systems maximum power point (MPP) based on the operation point. Appl Sci 7(9):870. https://doi.org/10.3390/app7090870

Derick M, Rani C, Rajesh M, Farrag ME, Wang Y, Busawon K (2017) An improved optimization technique for estimation of solar photovoltaic parameters. Sol Energy 157:116-124. https://doi.org/10.1016/j.solener.2017.08.006

Easwarakhanthan T, Bottin J, Bouhouch I, Boutrit C (1986) Nonlinear minimization algorithm for determining the solar cell parameters with microcomputers. J Sol Energy 4(1):1-12. https://doi.org/10.1080/01425918608909835

El-Naggar KM, AlRashidi MR, AlHajri MF, Al-Othman AK (2012) Simulated annealing algorithm for photovoltaic parameters identification. Sol Energy 86(1):266-274. https://doi.org/10.1016/j.solener.2011.09.032

Esmat R, Nezamabadipour H, Saryazdi S (2009). GSA: A gravitational search algorithm. Information Sciences 179(13):2232-2248. https://doi.org/10.1016/j.ins.2009.03.004

Ghalambaz M, Noghrehabadi AR, Behrang MA, Assareh E, Ghanbarzadeh A, Hedayat N (2011) A hybrid neural network and gravitational search algorithm (HNNGSA) method to solve well known Wessinger's equation. Int J Mech Mechatron Eng 5(1):147-151. https://doi. org/10.5281/zenodo. 1056974

Ghasemi A, Shayeghi H, Alkhatib H (2013) Robust design of multimachine power system stabilizers using fuzzy gravitational search algorithm. Int J Electr Power Energy Syst 51:190-200. https://doi.org/10.1016/j.ijepes.2013.02.022

Ghazali MR, Abas KH, Muhammad B, Aziz NAA, Lim KS (2017) MLGSA: Multi-leader gravitational search algorithm for multi-objective optimization problem. J Telecommun, Electron Comput Eng 9(1-4):119-123.

Lotsch HKV, Goetzberger A, Hoffmann VU (2005) Photovoltaic solar energy generation. Heidelberg: Springer. https://doi.org/10.1007/ b137803Harrag A, Messalti S (2015) GA-based solar cell parameters extraction application to single, double and triple diode models. Revue des Energies Renouvelables 18(4):701-711.

Harrag A, Messalti S (2017) Three, five and seven PV model parameters extraction using PSO. Energy Procedia 119:767-774. https:// doi.org/10.1016/j.egypro.2017.07.104 


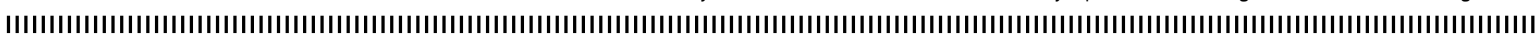

Hassanzadeh HR, Rouhani M (2010) A multi-objective gravitational search algorithm. Paper presented 2010 2nd International Conference on Computational Intelligence, Communication Systems and Networks. IEEE; Liverpool, United Kingdom. https://doi.org/10.1109/ CICSyN.2010.32

Huld T, Gottschalg R, Beyer HG, Topič M (2010) Mapping the performance of PV modules, effects of module type and data averaging. Sol Energy 84(2):324-338. https://doi.org/10.1016/j.solener.2009.12.002

Humada AM, Hojabri, M, Mekhilef S, Hamada HM (2016) Solar cell parameters extraction based on single and double-diode models: A review. Renew Sust Energ Rev 56:494-509. https://doi.org/10.1016/j.rser.2015.11.051

Jena D, Ramana VV (2015) Modeling of photovoltaic system for uniform and non-uniform irradiance: A critical review. Renew Sust Energ Rev 52:400-417. https://doi.org/10.1016/j.rser.2015.07.079

Ishaque K, Salam Z (2011) An improved modeling method to determine the model parameters of photovoltaic (PV) modules using differential evolution (DE). Sol Energy 85(9):2349-2359. https://doi.org/10.1016/j.solener.2011.06.025

Khajehzadeh M, Eslami M (2012) Gravitational search algorithm for optimization of retaining structures. Indian J Sci Technol 5(1):18211827. https://doi.org/10.17485/ijst/2012/v5i1.7

Khanna V, Das BK, Bisht D, Vandana, Singh PK (2015) A three diode model for industrial solar cells and estimation of solar cell parameters using PSO algorithm. Renew Energy 78:105-113. https://doi.org/10.1016/j.renene.2014.12.072

Kimber R, Gleeson DJ (1988) The electrical design of solar arrays for space use. Paper presented IEE Colloquium on Solar Cells for Space Applications. IET; London, United Kingdom. [accessed Nov 15 2019]. https://ieeexplore.ieee.org/abstract/document/209644

Kimber R, Goodbody C (1994) Achieving the optimum solar array size for spacecraft. Paper presented Intersociety Energy Conversion Engineering Conference. AIAA; Monterey, California, USA. https://doi.org/10.2514/6.1994-4049

Ley W, Wittmann K, Hallmann W (2009) Handbook of space technology. Hoboken: John Wiley \& Sons.

Luque A, Hegedus S (2003) Handbook of photovoltaic science and engineering. Hoboken: John Wiley \& Sons. https://doi. org/10.1002/0470014008

Mondal S, Bhattacharya A, nee Dey SH (2013) Multi-objective economic emission load dispatch solution using gravitational search algorithm and considering wind power penetration. Int J Electr Power Energy Syst 44(1):282-292. https://doi.org/10.1016/j. ijepes.2012.06.049

Morozov EV, Lopatin AV (2011). Design and analysis of the composite lattice frame of a spacecraft solar array. Compos Struct 93(7): 16401648. https://doi.org/10.1016/j.compstruct.2010.12.007

Oliveira PBM, Oliveira J, Cunha JB (2018) Trends in gravitational search algorithm. In: Omatu S, Rodríguez S, Villarrubia G, Faria P, Sitek P, Prieto J, editors. Distributed computing and artificial intelligence. Paper presented 14th International Conference. DCAI 2017. Advances in Intelligent Systems and Computing. Springer; Cham, Switzerland. https://doi.org/10.1007/978-3-319-62410-5_33

Ortiz-Conde A, Sánchez FJG, Muci J (2006) New method to extract the model parameters of solar cells from the explicit analytic solutions of their illuminated $I-V$ characteristics. Sol Energy Mater Sol Cells 90(3):352-361. https://doi.org/10.1016/j.solmat.2005.04.023

Park J-Y, Choi S-J (2017) A novel simulation model for PV panels based on datasheet parameter tuning. Sol Energy 145(15):90-98. https://doi.org/10.1016/j.solener.2016.12.003

Rekioua D, Matagne E (2012) Optimization of photovoltaic power systems: modelization, simulation and control. London: Springer. https://doi.org/10.1007/978-1-4471-2403-0

Siddique N, Adeli H (2016) Applications of gravitational search algorithm in engineering. J Civ Eng Manag 22(8):981-990. https://doi. org/10.3846/13923730.2016.1232306

Steingrube S, Breitenstein O, Ramspeck K, Glunz S, Schenk A, Altermatt PP (2011) Explanation of commonly observed shunt currents in c-Si solar cells by means of recombination statistics beyond the Shockley-Read-Hall approximation. J Appl Phys 110(1):014515. https:// doi.org/10.1063/1.3607310

Taherbaneh M, Ghafooifard H, Rezaie AH, Rahimi K (2011) Evaluation end-of-life power generation of a satellite solar array. Energy Convers Manag 52(7):2518-2525. https://doi.org/10.1016/j. enconman.2010.12.024

Tian H, Yuan X, Ji B, Chen Z (2014) Multi-objective optimization of short-term hydrothermal scheduling using non-dominated sorting gravitational search algorithm with chaotic mutation. Energy Convers Manag 81:504-519. https://doi.org/10.1016/j. enconman.2014.02.053

Wei H, Cong J, Lingyun X, Deyun S (2011) Extracting solar cell model parameters based on chaos particle swarm algorithm. Paper presented 2011 International Conference on Electric Information and Control Engineering. IEEE; Wuhan, China. https://doi.org/10.1109/ ICEICE. 2011.5777246

Xiao W, Lind MGJ, Dunford WG, Capel A (2006) Real-time identification of optimal operating points in photovoltaic power systems. IEEE Trans Ind Electron 53(4):1017-1026. https://doi.org/10.1109/TIE.2006.878355 